\title{
WOULD THE ELIMINATION OF AFFIRMATIVE ACTION AFFECT HIGHLY QUALIFIED MINORITY APPLICANTS? EVIDENCE FROM CALIFORNIA AND TEXAS
}

\author{
David Card \\ Alan B. Krueger \\ Working Paper 10366 \\ http://www.nber.org/papers/w10366 \\ NATIONAL BUREAU OF ECONOMIC RESEARCH \\ 1050 Massachusetts Avenue \\ Cambridge, MA 02138 \\ March 2004
}

We are grateful to Jesse Rothstein, Melissa Clark, and Stacy Dale Berg for valuable assistance, and to participants at the CLE Labor Lunch for comments. We also thank the Andrew Mellon Foundation for financial support and the College Board for making the data available. The views expressed herein are those of the authors and not necessarily those of the National Bureau of Economic Research.

(C2004 by David Card, and Alan B. Krueger. All rights reserved. Short sections of text, not to exceed two paragraphs, may be quoted without explicit permission provided that full credit, including (C) notice, is given to the source. 
Would the Elimination of Affirmative Action Affect Highly Qualified Minority Applicants?

Evidence from California and Texas

David Card and Alan B. Krueger

NBER Working Paper No. 10366

March 2004

JEL No. I28, J78

\begin{abstract}
Between 1996 and 1998 California and Texas eliminated the use of affirmative action in college and university admissions. At the states' elite public universities admission rates of black and Hispanic students fell by 30-50 percent and minority representation in the entering freshman classes declined. In this paper we ask whether the elimination of affirmative action caused any change in the college application behavior of minority students in the two states. A particular concern is that highly qualified minorities - who were not directly affected by the policy change would be dissuaded from applying to elite public schools, either because of the decline in campus diversity or because of uncertainty about their admission prospects. We use information from SATtakers in the two states to compare the fractions of minority students who sent their test scores to selective state institutions before and after the elimination of affirmative action. We find no change in the SAT-sending behavior of highly qualified black or Hispanic students in either state.
\end{abstract}

David Card

Department of Economics

UC Berkeley

Berkeley, CA 94720-3880

and NBER

card@econ.berkeley.edu
Alan B. Krueger

Department of Economics

Princeton University

Princeton, NJ 08544

and NBER

akrueger@princeton.edu 
Since the late 1960s most of the nation's elite colleges and universities have used affirmative action policies to boost the admission rates of black and Hispanic students. ${ }^{1}$ Although the legal status of race-based preferences has always been controversial, the Supreme Court's 1978 Bakke decision created a foothold by permitting the use of race as one factor in the evaluation of college applicants. Recently, however, affirmative action has come under renewed attack and in 1996-97 two major state systems - in California and Texas - halted the use of race-based preferences. The effect on minority admission rates at the elite public universities in the two states was immediate. At UC Berkeley the fraction of black and Hispanic applicants who were offered admission fell from approximately one-half to one quarter. At Texas A\&M the admission rates of black and Hispanic applicants fell from 90 percent to 70 percent. Roughly parallel declines occurred in the minority fractions of entering freshmen, leading to a drop in the racial and ethnic diversity of the student bodies at these campuses. ${ }^{2}$

In this paper we study the effects of the rollback of affirmative action in California and Texas on the college application behavior of minority students in the two states. Our main focus is on the behavior of highly qualified minority applicants. Although students with high test scores and good high school grades were not directly affected by the policy change, their application decisions reveal important insights into the potential social consequences of ending affirmative action. To the extent that highly qualified minorities value racial and ethnic diversity, for example, the drop in overall minority admissions at the elite public schools in California and Texas might lead them to

\footnotetext{
${ }^{1}$ See Bowen and Bok (1998, pp. 1-14) for a brief history of affirmative action policies in college admissions. Kane (1998) summarizes the extent of affirmative action at elite institutions in the mid 1990s. Throughout this paper, we use "minority" to refer to African American and Hispanic students. These two groups, plus American Indians, are classified as "underrepresented minorities" by the University of Californian and many other institutions.

${ }^{2}$ For example, the minority share of entering freshmen at Berkeley fell from $22 \%$ in fall 1997 (the last cohort admitted with race preferences) to $12 \%$ in 1998 , while at Texas A\&M the minority share of entering freshmen fell from $20 \%$ in 1995 to $12 \%$ in 1997. Sources for these statistics are described in Section I below.
} 
apply elsewhere, intensifying the impact of the switch to race-blind admissions. Moreover, in the presence of uncertainty about their admission prospects, the elimination of affirmative action may cause highly qualified minority applicants to redirect their search toward less competitive public institutions, or to other institutions where affirmative action remained in effect. Alternatively, if highly qualified minority students are stigmatized by being part of a less-qualified group, they may actually prefer institutions with race-blind admissions, leading to a rise in applications after the lifting of affirmative action. ${ }^{3}$

Our analysis is based on confidential micro data for the population of SAT-takers in California and Texas over the period from 1994 to 2001. Both states have relatively high SAT participation rates and both require standardized tests for admission to public four-year colleges and universities. ${ }^{4}$ SAT-takers designate a list of institutions to receive their scores. Although test-takers don't necessarily apply to every school on the list, and can apply to other schools not on the list, an analysis of California data shows that the number of students in a given racial/ethnic group who send scores to a particular institution is highly correlated with the number who actually apply. In light of this, we use SAT-takers data to track the application behavior of minority students, and test whether the elimination of affirmative action in Texas and California led to changes in the behavior of different race/ethnic and ability groups. In particular, we analyze changes in the propensity of minority students to send their scores to the most selective public institutions. We also examine other features of their application behavior, including the number of schools designated by each

\footnotetext{
${ }^{3}$ Turner and Pratkanis (1994) present a survey of the social psychology literature on perceptions of affirmative action by target group members. See also Society for Industrial and Organizational Psychology (undated). Schotter and Weigelt (1992) analyze results of an experiment designed to test the reaction of participants to "affirmative-action" type payment systems.

${ }^{4}$ Institutions in both states accept the ACT in place of the SAT. In both California and Texas, however, a relatively small fraction of high school students take only the ACT exam. See Clark (2003).
} 
student and the lower quality bound of the schools on the list. Perhaps surprisingly, we find no evidence that the elimination of affirmative action had systematic effects on any of these dimensions of application behavior for highly qualified minority students in either California or Texas.

I. Affirmative Action and Admissions at Selective Public Institutions in California and Texas

a. The Situation Before 1996

Prior to the elimination of affirmative action, a relatively high fraction of minority students at the University of California (UC) were admitted "by exception" - i.e. by a process that bypassed the standards for high school grade point averages and standardized test scores. ${ }^{5}$ For example, in 1996 23\% of black freshman enrollees and 11\% of Hispanic (Chicano and Latino) enrollees were classified as admitted by exception, compared with approximately $2 \%$ of Asian and white enrollees (UC Office of the President, 1998). Most of the minority students admitted by exception were at the three most selective UC campuses: Berkeley, UCLA, and UC San Diego. In Texas, the state's selective undergraduate institutions (Texas A\&M University, University of Texas at Austin, Texas Tech University, Southwest Texas State University, University of Houston, and University of North Texas) are administered under a variety of different systems and comparable data on the extent of affirmative action are unavailable. ${ }^{6}$ Nevertheless, a campus-by-campus survey of admission policies in Sharp (1999, chapter 2) suggests that the two most selective institutions, Texas A\&M and UT

${ }^{5}$ The California system of higher education also includes the California State Universities. Until very recently, these institutions admitted all students who met certain admission standards.

${ }^{6}$ According to Sharp (1999) the Texas Higher Education Coordinating Board identifies 8 selective undergraduate institutions. However, two of these are relatively small and we follow Sharp (1999) and Thomas (2002) in focusing on these 6. University of Texas schools, including UT Austin, offer "provisional admission" to all high school graduates with the requisite number of high school course. These students must earn a 2.0 GPA or better in summer classes to enter in the fall. Because of this policy, it is unclear whether UT Austin should be considered highly selective. 
Austin, operated significant affirmative action policies in $1995^{7}$

One crude indicator of the extent of affirmative action is the gap between admission rates of minority and non-minority applicants. Table 1 presents admission data for the eight UC campuses and the six selective Texas state institutions in 1995, including the admission rates of all applicants and of minority applicants. We also show the characteristics of the "SAT-sending" pool for each institution - the set of students who sent their SAT scores to the campus in question for admission in fall 1994-1996. ${ }^{8}$ Since not all SAT-senders actually apply to an institution and some applicants write the ACT rather than the SAT, the SAT-sending pool differs from the actual applicant pool. As we discuss later in the paper, however, we believe that the characteristics of the SAT-sending pool provide useful information on the characteristics of the actual admission pool.

Consistent with the existence of significant affirmative action programs, black and Hispanic students were admitted at relatively high rates at the most selective California and Texas universities just prior to the elimination of affirmative action. Indeed, at UCLA, Berkeley, UT Austin, and Texas A\&M, minority applicants had higher average acceptance rates than other groups in 1995. This is particularly remarkable in light of the disparity in qualifications between minority and nonminority SAT-senders in the two states. For example, the difference in average SAT scores between minority SAT-senders and the overall pool was about 150 points at the three most selective UC campuses, and approximately 100 points at the other UC campuses and the selective Texas schools. Similarly, there was a 15-20 percentage point gap in the fraction of students with at least an

\footnotetext{
${ }^{7}$ Sharp (1999) only discusses data from 1995-1997. Evidence on the fraction of minority freshman enrollees at Texas A\&M gathered by Bucks (2003) shows a steadily rising minority fraction in the early 1990s: from $12 \%$ in 1991 to $20 \%$ in 1995 . It is unclear whether this represents changing admission policies or trends in the applicant pool. Bucks' data for UT Austin show a fairly steady $20 \%$ minority enrollment share of freshman enrollees over the same period.
}

${ }^{8}$ These data are based on all SAT takers in the two states in the 1994-1996 college entry cohorts. The SAT takers data set is described more fully below. 
A-minus grade point average between the overall SAT-sending pool and minority pool at the most selective UC campuses, and a 10-point gap at the other UC campuses and the Texas schools.

The relatively high admission rates of minority applicants at UCLA, UC Berkeley, and Texas A\&M, coupled with the fact that minority students offered admission at these schools had relatively high enrollment rates, meant that the entering freshman classes at these campuses had even higher minority representation than the applicant pools (compare column 7 and column 2 of Table 1). At most of the other selective institutions in the two states, the fraction of minority enrollees was slightly lower than the fraction of minority applicants, reflecting a combination of lower minority admission rates and lower minority enrollment rates, conditional on admission. The force of affirmative action programs was therefore most visible at the elite public institutions of California and Texas. Similarly, Kane's (1998) analysis suggests that the impact of affirmative action in the 1990s was confined to the most selective $20 \%$ of colleges and universities nationwide.

\section{b. The Elimination of Affirmative Action in California and Texas}

In California the elimination of race-based admission policies in public higher education arose through a political process. The Board of Regents of the University of California, acting with the support of the Governor, voted in 1995 to eliminate affirmative action in admissions starting in fall 1998 (see National Association for College Admission Counseling, 2001). Before the policy could take effect, however, an election was held on a statewide proposition (Proposition 209) that outlawed the use of affirmative action in the areas of public employment, public education, and public contracting. ' Proposition 209 was passed by voters in November 1996, but only became law

'The Regents' vote and the Proposition were closely linked. Proposition 209 was sponsored by the California Civil Rights Initiative, an anti-affirmative action group headed by Ward Connerly, who was also a member of the Board of Regents and a leading force in the Regents' vote to end affirmative action. 
after a year-long series of appeals. As originally planned by the Board of Regents, affirmative action in UC admissions ended with the 1998 freshman cohort.

In Texas the elimination of affirmative action stemmed from a 1992 lawsuit filed by Cheryl Hopwood and others challenging the constitutionality of the admission process at the University of Texas School of Law. The federal district court initially ruled that the use of race-based admission preferences was legal, although it struck down the school's "two-track" admission system. In March 1996, however, the Fifth Circuit Court of Appeals reversed the lower court, declaring that the goal of a diverse student body is ..."not of sufficient compelling interest to support the use of race as a factor in admissions" (Hopwood v. State of Texas, 78 F.3d 932, $5^{\text {th }}$ Circuit 1996). After the Supreme Court refused to hear the case, the Appeals Court ruling was interpreted by the Texas Attorney General as outlawing the use of racial preferences in college admissions. Thus, starting with the freshman class of 1997, affirmative action policies were ended in Texas public colleges and universities.

The halt in affirmative action in California had an immediate impact on the relative admission rates of minority applicants at the most selective UC campuses. Figure 1a shows the admission rates of black freshman applicants at Berkeley, UCLA, and UC San Diego, and in the UC system as a whole before and after 1998, while Figure 1b reports the same statistics for Hispanic applicants. ${ }^{10}$ Admission rates of black applicants at the three most selective campuses fell from 4555 percent in the 1995-1997 period to 20-25 percent in 1998-2001. Admission rates of Hispanic applicants show a similar decline, although there was a slight downward trend at UCLA and

\footnotetext{
${ }^{10}$ These data are taken from University of California Office of the President (2003).
} 
Berkeley even before 1998. ${ }^{11}$ In contrast to the large drops at the three most selective UC campuses, systemwide acceptance rates fell by less - roughly 7 percentage points for black applicants and 4 percentage points for Hispanics. The difference reflects the fact that many students apply to both highly selective and less selective UC campuses, and that minority admission rates at the least selective UC campus (UC Riverside) were relatively unaffected by the elimination of affirmative action. ${ }^{12}$

Evidence on the effects of the Hopwood decision is clouded by several factors, including yearto-year variability in admission rates at the Texas schools, lack of consistent data (especially in regard to the handling of provisionally admitted students), and the implementation of a new policy effective in fall 1998 - that guaranteed automatic admission to any Texas campus for high school students who graduated in the top 10 percent of their class. Nevertheless, as shown in Figure 2a and $2 \mathrm{~b}$, available data suggest that the admission rates of black and Hispanic freshman applicants at Texas A\&M and UT Austin both declined relative to whites and Asians after 1996. ${ }^{13}$ At Texas A\&M the decline began in 1996 and continued through1997. Sharp (1999, p. 26) suggests that this gradual transition arose because admission officials had partially responded to the Hopwood decision by fall 1996. Assuming that this is the case, and that minority admission rates in 1995 provide a valid counterfactual for admissions in the absence of Hopwood, we estimate that the elimination of

\footnotetext{
${ }^{11}$ Although the data are not shown, admission rates for Asian and white applicants at the three campuses were trending smoothly over the 1995-2001 period.

${ }^{12}$ At UC Riverside, average admission rates of black applicants were 67\% in 1995-97 and 68\% in 19982001, while average admission rates of Hispanic applicants were 79\% in 1995-97 and 80\% in 1998-2001. At the second least selective UC campus, UC Santa Cruz, average admission rates for blacks were $78 \%$ in 1995 97 and $65 \%$ in 1998-2001, while for Hispanics the averages were $84 \%$ in $1995-97$ and $77 \%$ in 1998-2001.

${ }^{13}$ The data in Figure 2 for 1995-1997 are taken from Sharp (1999, Tables 1b and 2b) and refer to first time Texas freshman applicants. The 1999-2001 data are taken from annual statistical summaries reported by the Texas Higher Education Coordinating Board (THECB, various years), and also refer to first time Texas undergraduate applicants. The UT Austin admission rate data include provisional admits as admitted.
} 
affirmative action at Texas A\&M lowered Hispanic admission rates by 15 percentage points and black admission rates by 30 percentage points. At UT Austin a similar pattern is discernable, although the relative decline in minority admittance rates continued after 1997. In particular, black and Hispanic admission rates fell by 5-7 percentage points relative to whites and Asians between 1995 and 1997, and by another 4-5 percentage points between 1997 and 2001.

Abstracting from changes in applicant flows (or assuming these are fixed in the short run), the effects of ending affirmative action on the racial and ethnic makeup of the student body depend on the relative admission rate of minority students and on the relative fraction of admitted minority students who decide to enroll (i.e., the relative yield rate). At the three most selective UC campuses the relative yield rate of minority students rose slightly between 1997 and 1998 (by about 10\%), partially offsetting the 50-60 percent declines in minority admission rates. ${ }^{14}$ Nevertheless, the shortrun effect of ending affirmative action was a sharp decline in the ethnic diversity of entering freshmen. Between 1997 and 1998 the fraction of minorities in the freshman class fell from $22 \%$ to $12 \%$ at UC Berkeley; from $22 \%$ to $15 \%$ at UCLA; and from $13 \%$ to $10 \%$ at UC San Diego.

At Texas A\&M, data reported by Sharp (1999, Table 1b) show a small (3 percent) relative decline in the yield rate of minority versus non-minority admittees between 1995 and 1997. Coupled with the roughly 20 percent decline in the admission rate of minority applicants and the 10 percent rise in the admission rate of non-minorities, these trends imply a 33 percent decline in the fraction of minorities among newly entering freshmen. The actual drop was only slightly larger. ${ }^{15}$ At UT Austin, yield rate data presented by Tienda et al. (2003) suggest that the minority yield rate was fairly

\footnotetext{
${ }^{14}$ The rise in enrollment rates of admitted minorities may have been due in part to the change in the composition of the admitted minority pool, and in part to efforts of the UC campuses to increase minority yield rates after the elimination of affirmative action.

${ }^{15}$ Data reported by Bucks (2003) based on different data sources show a 37 percent decline in the minority fraction of freshman enrollees between 1995 and 1997.
} 
stable before and after the Hopwood decision. Thus, the 6 percent decline in the relative admission rate of minority applicants between 1995 and 1997 would have been expected to lead to a proportional decline in the fraction of minority students among newly enrolling freshmen. The actual decline was larger than this (about 20 percent, according to data in Bucks, 2003) suggesting an immediate shift in the minority share of applicant flows. ${ }^{16}$

\section{The Effect of Affirmative Action Policies on Applicant Behavior}

\section{a. A Model of Application Behavior}

Most existing studies of college choice (Kohn et al., 1976; Fuller et al. 1982; Brewer, Eide, and Ehrenberg, 1999) have ignored the application process and focused on which college a student actually attends. ${ }^{17}$ Admission to elite public and private schools is uncertain, however, and applicants to these institutions must recognize that they may not be admitted to any given school. To model the effects of ending affirmative action on the decision to apply to elite public schools, we assume that a student assigns utility $\mathrm{U}_{\mathrm{i}}$ to attending institution $\mathrm{i}$. The level of $\mathrm{U}_{\mathrm{i}}$ depends on factors like the quality of the institution, tuition and financial aid, the racial/ethnic composition of the student body, and perceptions of campus attitudes and values. A student also attaches a probability $\mathrm{p}_{\mathrm{i}}$ to the likelihood of being admitted at school $\mathrm{i}$. (For simplicity we assume that the admission decisions of different schools are independent). Finally, we assume there is a cost $\mathrm{d}$ of applying to

\footnotetext{
${ }^{16}$ As noted earlier, data on UT Austin applicants and admission rates varies from source to source so any conclusions have to be drawn very carefully.

${ }^{17}$ Long (2002) is an exception. Like us, Long studies the effect of ending affirmative action on minority students' decisions about where to sent their SAT scores. However, his data set lacks the identities of the specific schools listed by each student. Instead, he has information on a selectivity ranking of the different institutions and whether they are public or private and 2 or 4 year institutions. Dale and Krueger (2002) do not explicitly model the decision of where to apply, but they use information on the set of schools applied to by a student as a control for unobserved ability.
} 
each school, and let $\mathrm{U}_{0}$ represent the utility of not attending college. ${ }^{18}$

In this setup optimizing behavior generates an application set $\mathrm{C}$ consisting of an ordered list of J schools (with $\mathrm{U}_{1} \leq \mathrm{U}_{2} \leq \ldots . \leq \mathrm{U}_{\mathrm{J}}$ ). Necessary conditions for a school to be included in $\mathrm{C}$ are that the student is willing to go there (i.e., $\mathrm{U}_{\mathrm{i}}>\mathrm{U}_{0}$ ) and that the student's probability of acceptance is strictly positive. For a given choice set $C$ let $\pi_{j}=p_{j} \times \Pi_{i=j+1}^{j}\left(1-p_{i}\right)$ represent the probability that choice $\mathrm{j} \in \mathrm{C}$ is the best available, and let $\pi_{0}=\Pi_{\mathrm{j}=1}^{\mathrm{J}}\left(1-\mathrm{p}_{\mathrm{j}}\right)$ represent the probability that the applicant is admitted to none of his or her choices. Taking account of the cost of applying to J schools, the applicant's expected utility is $U^{*}=\sum_{j=0}^{J} \pi_{j} U_{j}-d J$.

Holding constant the $U_{i}$ 's and the admission probabilities at other schools, this model implies that a student will apply to a given school if and only if $\mathrm{p}_{\mathrm{i}}$ is above some threshold value for the school. To see this, let $\mathrm{C}(\sim \mathrm{k})$ denote the optimal choice set when school $\mathrm{k}$ is excluded from consideration, and let $\mathrm{J}(\sim \mathrm{k})$ represent the number of schools in this set. School $\mathrm{k}$ will be included in the final choice set if and only if

$$
\mathrm{p}_{\mathrm{k}}\left\{\Pi_{\mathrm{j}=0}^{\mathrm{J}(\sim \mathrm{k})} \pi_{\mathrm{j}} \max \left[0, \mathrm{U}_{\mathrm{k}}-\mathrm{U}_{\mathrm{j}}\right]\right\}-\mathrm{d}>0 .
$$

The first term in this expression is the option value of applying to school $\mathrm{k}$ when the choice set is $\mathrm{C}(\sim \mathrm{k})$. This is just the probability that the applicant is admitted to school $\mathrm{k}$, multiplied by the expected gain in being able to attend school $\mathrm{k}$ over the alternatives in $\mathrm{C}(\sim \mathrm{k})$. This option value has to be greater than the marginal application cost if $\mathrm{k}$ is included in the optimal choice set. Since the expression in braces does not depend on $\mathrm{p}_{\mathrm{k}}$, this expression generates a threshold admission probability for school $\mathrm{k}$. A fall in $\mathrm{p}_{\mathrm{k}}$ can therefore cause some students who previously applied to school $\mathrm{i}$ to drop it from their choice set. Similar reasoning applies to the $\mathrm{U}_{\mathrm{i}}$ 's: holding constant

\footnotetext{
${ }^{18}$ We interpret $\mathrm{d}$ as including the application fee (currently, for example, $\$ 40$ per campus of the University of California) plus the costs of filling out forms, completing essays, etc.
} 
admission probabilities and utilities for other choices, there is a threshold utility level for school i. If a change in admission policy lowers a student's perceived utility from attending a given campus, she may drop the school from her application set.

A related implication is that changes in the probability of admission at more preferred schools can lead to changes in the likelihood of applying to less preferred schools. For example, consider a non-selective "safety school" that is ranked below the lowest-ranked school in C but above the alternative of no college (i.e., a school with $\mathrm{p}_{\mathrm{k}}=1$ and $\mathrm{U}_{0}<\mathrm{U}_{\mathrm{k}}<\mathrm{U}_{1}$ ). The option value of applying to this school is

$$
\left\{\Pi_{\mathrm{j}=1}^{\mathrm{J}}\left(1-\mathrm{p}_{\mathrm{j}}\right)\right\} \times\left[\mathrm{U}_{\mathrm{k}}-\mathrm{U}_{0}\right],
$$

which depends only on the probability of not being accepted at any of the schools in C, and on the gap between $\mathrm{U}_{\mathrm{k}}$ and the no-college option. A fall in the probability of acceptance at more highly ranked schools will lead to an increase in the option value of such schools, potentially leading the student to apply to previously unattractive schools.

This simple model highlights three channels for changes in affirmative action to affect the probability that a student applies to a specific school: through changes in the probability of admission at that school; through changes in the utility of attending the school; and through changes in the probability of admission at other schools. For less-qualified minority students, the elimination of affirmative action affects the likelihood of applying to elite public schools though the first two channels. Assuming that minority applicants value a bigger minority presence on campus, both channels will tend to lower application rates to elite public schools and raise application rates to lessselective institutions.

The impacts on the application decisions of highly qualified minority students are less clear cut. Assuming that these students know they will be admitted to elite public schools regardless of 
affirmative action, the only impact of ending affirmative action is through an effect on the utility of attendance. If highly qualified minorities value a larger minority presence on campus, they will assign a lower utility to attending elite public schools in the post affirmative action era, leading to a reduction in application flows. At the same time, they may raise their assessments of lower-ranked public schools in anticipation of larger inflow of minority students after the end of affirmative action. Thus, like their less qualified peers, highly qualified minority students will be diverted from elite public schools to lower-ranked institutions.

An important caveats to this reasoning is that students have imperfect information on their actual admission prospects at any given school. This is particularly true for first-time SAT-takers, who may not be able to predict their test outcomes very well. Moreover, admission probabilities at elite schools are typically less than 100\% even for students with high test scores and strong high school grades. This uncertainty blurs the distinction between highly qualified and less qualified minority applicants, and makes it more likely that even highly qualified minority students perceive some risk of a decline in their probability of admission at elite public schools, lowering the likelihood that they will apply to these schools. It is also possible that some highly qualified minority students actually prefer a "non-affirmative action" campus environment, and put little or no weight on the relative number of minority students on campus. These preferences could lead to a rise in applications by some highly qualified minority students to the elite public colleges after the end of affirmative action.

Since our research design focuses on changes in the probability of applying to elite schools by minorities relative to non-minorities, it is also worth considering the effect of ending affirmative action on white and Asian students. Presumably, the elimination of racial preferences has a small 
positive effect on admission probabilities for non-minority applicants. ${ }^{19}$ Assuming that nonminorities place little or no value on the fraction of minorities on campus, this would be expected to lead to a small increase in the likelihood of applying to the elite public schools after the end of affirmative action.

\section{b. SAT Takers Data}

We now turn to an analysis of the behavioral responses of minority applicants to the elimination of affirmative action in California and Texas. Our data are derived from the College Board's Test Takers Data Base, and include all SAT-takers in California and Texas in the 1994-2001 admission cohorts. Since students can write the test multiple times, the College Board defines cohorts based on their high school completion dates. For example, the 1994 cohort includes students who would be expected to finish high school in spring 1994 and enter college the following September. ${ }^{20}$ Basic information on the characteristics of the SAT takers by state and year is presented in Appendix Table $1 .^{21}$

Over the 1994-2001 period the annual number of SAT takers rose steadily in California and Texas, reflecting a combination of rising numbers of high school graduates and increasing test

\footnotetext{
${ }^{19}$ If the total number of students admitted remains constant then the effect on the admission rate of nonminorities is $\mathrm{p}_{\mathrm{m}} /\left(1-\mathrm{p}_{\mathrm{m}}\right)$ times as big as the effect on the admission rate of minorities, where $\mathrm{p}_{\mathrm{m}}$ is the fraction of minorities in the applicant pool. For the elite public schools in California and Texas this ratio was about 0.25 .

${ }^{20} \mathrm{We}$ do not know how many times a student has taken the test. The data set includes only the most recent test results and most recent background information. Most of the records are for students in their senior year $(73.9 \%)$. Nearly all the remaining records $(25.7 \%)$ are for students in their junior year.

${ }^{21}$ We restrict attention to the $85 \%$ of test-takers who designated at least one school to receive their test scores. The excluded group are more likely to have taken the test in their junior year, and have lower average scores, lower cumulative GPA's, and are more likely to be black or Hispanic.
} 
participation. $^{22}$ Test takers report their ethnicity and other academic and family background information in the Student Descriptive Questionnaire component of the SAT. The ethnic categorization is a combination of race and Hispanic origin. ${ }^{23}$ Both California and Texas have high fractions of minority test-takers $(6 \%$ black and 18\% Hispanic in California; $10 \%$ black and 20\% Hispanic in Texas). California also has a high fraction of Asian test takers (22\%). A striking trend in both states is the rise in the fraction of test-takers who decline to state their ethnicity. ${ }^{24}$ In both states, the increase seems to have started in 1996 (i.e., around the time of the elimination of affirmative action) and was accompanied by a parallel decline in the fraction of white non-Hispanic test-takers. Based on this pattern we infer that most non-identified test takers are white.

Mean SAT scores are slightly higher in California than Texas, whereas high school GPA's are higher in Texas. For example, 44\% of Texas test-takers reported a GPA of A-minus or better in 1994, versus 36\% in California. Over the 1990s high school grades rose in both states, with 50\% of Texans and $43 \%$ of Californians reporting an average of A-minus or better by 2001 . SAT-takers also report their class rank, and unlike the GPA distributions the class rank distributions are similar in the two states and fairly stable over time. Roughly one fifth of SAT takers report that they are in the top 10 percent of their class, and another fifth report they are in the second decile.

Table 2 presents comparisons by ethnicity of SAT-takers' outcomes in the two states. To set the stage for our later analysis, the table shows means for each group from the period before (1994-

\footnotetext{
${ }^{22}$ Over the 1990 s the number of graduates of public high schools was rising at $2.4 \%$ per year in California and $1.7 \%$ per year in Texas, compared with growth rates of $2.8 \%$ and $3.7 \%$ respectively in the number of SAT-takers in our data set.

${ }^{23}$ The specific categories are: (1) American Indian or Alaskan Native; (2) Asian, Asian American, or Pacific Islander; (3) Black or African American; (4) Mexican or Mexican American; (5) Puerto Rican; (6) Latin American, South or Central American, or other Hispanic or Latino; (7) White; (8) Other.

${ }^{24}$ The fraction of non-reporters in California rose from 5\% in 1996 to $13 \%$ in 2001, and in Texas from $3 \%$ in 1996 to $10 \%$ in 2001 in Texas.
} 
1996) and after (1999-2001) the elimination of affirmative action. Several key patterns are evident in the table. First, average SAT scores are lower for black and Hispanic students than for whites and Asians. Mean scores for blacks are about 200 points below the average for whites, while means for Hispanics are 140-180 points lower. Second, ethnic differences in SAT outcomes are not too different before and after 1997. Third, although black and Hispanic students have lower GPA's and are less likely to be in the top rank of their class, the disparity with whites in class room achievement is smaller than the disparity in test scores. For example, pre-1997, California blacks were only onefifth as likely as whites to score 1150 or better on the SAT, but were one-third as likely to report at least an A average, and 38\% as likely to report being in the top decile of their class. (Similar comparisons hold for Hispanics and for both groups in Texas). The relatively smaller minority gaps in class performance than test scores could reflect differences in average grading standards and peer groups in schools attended by minorities, or inherent differences in minority test performance conditional on class performance (Steele and Aronson, 1998), or both. ${ }^{25}$

Before writing the SAT, students designate a list of institutions to receive their test scores. Test takers can specify up to four schools to receive their scores without charge, and four more for an additional fee (currently, $\$ 6.50$ per school). After the test is completed, they can add additional schools to the list for the same incremental fee. Our data set includes the identities of up to 20 institutions that each SAT taker designated to receive his or her test scores. (Only 1 percent of test takers designate more than 14 schools). We summarize information on the characteristics of the list of schools in the four right-hand columns of Table 2.

\footnotetext{
${ }^{25}$ Rothstein (2003) estimates models that relate college grades (for UC students who entered in Fall 1993) to high school grades and SAT scores. He concludes that the SAT captures differences across schools that are correlated with minority share and parental income but are not reflected in high school grades. This is consistent with the peer group/grading standards interpretation of the larger gap in SAT scores than grades.
} 
On average, SAT takers send their scores to 5-6 institutions, with a tendency for Asian students to send their scores to more schools and Hispanics to send their scores to fewer. We classify a student as sending scores to a selective public institution if he or she sent scores to one of the schools listed in Table 1, and to an elite public school if the list includes UCLA, Berkeley or UC San Diego (for California students) or Texas A\&M or UT Austin (for Texas students). For comparison purposes, we also present probabilities of sending scores to one or more of the major in-state private institutions: University of Southern California, Stanford, University of San Diego, and the Claremont Colleges in California; Baylor, Rice, and Trinity University in Texas.

There are notable differences across ethnic groups in the probabilities of sending scores to different types of institutions. For example, in both California and Texas, black students are less likely than whites to send scores to selective public institutions. When the comparison is narrowed to elite schools, however, blacks in California are about as likely as whites to submit their scores, whereas blacks in Texas are much less likely. Some of these differences may reflect the location of the elite versus other selective campuses in the two states. Two of the most selective University of California campuses, UCLA and Berkeley, are located in large urban areas, whereas many of the other UC campuses are not. By comparison, UT Austin and Texas A\&M are located in small cities with relatively low minority shares, while several of the other Texas schools are in urban environments. These considerations suggest that it is probably most useful to focus on changes in the relative propensity of different groups to send their scores to different institutions after the elimination of affirmative action, rather than on the levels at any particular time. Looking at the simple means in Table 2, there is little evidence of a systematic fall off in interest of minority students in the elite or other selective public institutions in California or Texas. 


\section{c. Sending SAT Scores versus Applying}

Is it appropriate to interpret changes in the probability of sending SAT scores to different institutions as changes in application behavior? Ideally, it would be possible to test this interpretation using micro data for a sample of students who report both the schools to which they applied and the ones to which they sent their test scores. We are unaware of any such data. As an alternative, we collected administrative data for the eight UC campuses on the number of applicants by ethnicity in each year from 1995 to 2001 . We then calculated the number of students in each ethnic group who sent their SAT scores to each of these institutions, and compared the numbers of applicants and SAT-senders.

Specifically, we fit a series of regression models of the form:

$$
\log \left(\mathrm{S}_{\mathrm{jct}}\right)=\delta_{\mathrm{jt}}+\gamma_{\mathrm{c}}+\lambda \log \left(\mathrm{A}_{\mathrm{jct}}\right)+\epsilon_{\mathrm{jct}},
$$

where $S_{\text {jct }}$ is the number of California students in ethnic group $j$ who sent their SAT scores to campus $\mathrm{c}$ for admission in year $\mathrm{t}, \mathrm{A}_{\mathrm{jct}}$ is the number of first time freshman applications from California residents in ethnic group $\mathrm{j}$ at campus $\mathrm{c}$ in year $\mathrm{t}, \delta_{\mathrm{jt}}$ represents an unrestricted dummy for each ethnic group in each year, $\gamma_{\mathrm{c}}$ represents a dummy for each campus, and $\epsilon_{\mathrm{jct}}$ is a residual. Under reasonable assumptions, the coefficient $\lambda$ in this equation provides an estimate of the degree of attenuation bias that would be expected when the fraction of students in a given ethnic group who send their SAT scores to a particular campus is used as a dependent variable in place of the fraction who actually apply to the campus. ${ }^{26}$ Estimation results for several different specifications of

\footnotetext{
${ }^{26}$ To see this let $\mathrm{N}_{\mathrm{it}}$ represent the number of graduating high school seniors in ethnic group $\mathrm{j}$ in year $\mathrm{t}$, let $A_{\text {jct }}$ represent the number of these who apply to campus c, and let $S_{\text {ict }}$ represent the number who send their SAT scores to campus c. Let $\pi_{\text {ict }}=A_{\text {ict }} / N_{i t}$ represent the application rate and $\mu_{\text {ict }}=S_{\text {ict }} / N_{\text {it }}$ represent the SATsending rate. Suppose the model of interest is $\log \pi_{\text {ict }}=X_{\text {jct }} \beta+Z_{\text {ict }} \gamma+e_{\text {ict }}$, where $Z_{\text {ict }}$ represent a set of basic controls (e.g., dummies for year, ethnic group, and campus) and $\mathrm{X}_{\text {ict }}$ represents a set of covariates of primary interest (e.g., interactions of year dummies and ethnic dummies). Consider the linear projection: $\left(^{*}\right) \quad \log \mu_{\mathrm{jct}}=\lambda \log \pi_{\mathrm{jct}}+\mathrm{Z}_{\mathrm{jct}} \phi+\mathrm{u}_{\mathrm{jct}}$.
} 
equation (1) are presented in Table 3.

The first column of the table shows estimates of equation (1) based on data for four ethnic groups (white non-Hispanics, Asians, blacks, Hispanics), 8 campuses and 7 years, while the third column reports results when the sample is restricted to the three most selective UC campuses (UCLA, Berkeley, and UC San Diego). In both cases the coefficient $\lambda$ is precisely estimated with a value just under 1, and the fraction of explained variance is very high ( $99 \%$ or better). These results suggest that trends in the number of applicants to a particular campus are closely mirrored by trends in the number of students who send their SAT scores to that campus, and that use of the probability of sending SAT scores to particular institution as a measure of the probability of applying to that institution would lead to relatively little attenuation bias. Columns (2) and (4) expand the model by adding a full set of "two-way" interactions between campus, ethnicity, and year dummies (i.e., campus-by-ethnicity and campus-by-year dummies in addition to the ethnicity-by-year dummies). These specifications provide a very stringent test of the "signal" in observed SAT-sending rates as measures of underlying application behavior. When the model is fit to all 8 campuses the estimate of $\lambda$ falls to 0.48 (but remains highly significant), whereas in the sample of most-selective campuses the estimate drops less, to 0.74. Based on these results we conclude that SAT-sending rates provide useful information on application rates, particularly for the most selective campuses, which are our main focus.

If $\mathrm{u}_{\mathrm{jct}}$ is orthogonal to $\mathrm{X}_{\mathrm{jct}}$ then a regression of SAT-sending rates on $\mathrm{X}$ and $\mathrm{Z}$ will yield an estimate of the effect of the X's that tends to $\lambda \beta$, rather than to $\beta$. (In the classical measurement error case $\lambda=1$ and there is no bias arising from the use of a noisy dependent variable). Equation $(*)$ implies that

$$
\log \mathrm{S}_{\mathrm{jct}}=\lambda \log \mathrm{A}_{\mathrm{jct}}+(1-\lambda) \log \mathrm{N}_{\mathrm{jt}}+\mathrm{Z}_{\mathrm{jct}} \phi+\mathrm{u}_{\mathrm{jct}} \text {. }
$$

Notice that if $Z$ includes unrestricted dummies for each ethnic group in each year then the number of graduates is absorbed by $Z$ and the estimate of $\lambda$ from this model can be used to infer the degree of attenuation bias when SAT sending rates are used in place of actual application rates. 


\section{d. Changes in Minority SAT-Sending}

We now turn to an analysis of the effects of ending affirmative action on the propensity of minority students to send their SAT scores to the selective public colleges and universities in California and Texas. The framework for our analysis is the difference-in-differences approach pioneered by Ashenfelter (1978). We compare the fraction of minority students who send their SAT scores to a particular set of institutions before and after the elimination of affirmative action, relative to trends for comparable non-minority students. A simplified set of comparisons is presented in Figures $3 \mathrm{a}$ and $3 \mathrm{~b}$ for California students, and in Figures $4 \mathrm{a}$ and $4 \mathrm{~b}$ for Texas students. Figure 3a, for example, shows the relative fraction of black versus white students in a particular SAT range who sent their scores to one or more of the most selective UC campuses. We divide students into three SAT ranges: those scoring below 1150; those scoring from 1150 to1300, and those scoring above 1300. As noted in Table 1, average scores for all applicants at UCLA, Berkeley, and UC San Diego are in the 1100-1150 range. Thus the first group of test takers could be considered less qualified, the second group more qualified, and the third group very highly qualified.

Inspection of Figures $3 \mathrm{a}$ and $3 \mathrm{~b}$ suggests a couple of tentative conclusions. First, controlling for the range of SAT scores, black and Hispanic students in California are more likely to send their scores to the most selective UC's than whites. Second, apart from blacks in the 1150-1300 score range, there is little indication of a relative change in the SAT-sending behavior of minority students in California after 1997. The relative trend for blacks with scores of 1150-1300 is positive between 1994 and 1996, then negative between 1996 and 1998, with a resumption of the positive trend after 1998. The negative trend in the $1996-98$ period is potentially consistent with at least a temporary reaction to affirmative action policy changes, although the fact that it started in 1996 (one year before the official end of affirmative action) and was only experienced by better-qualified students 
is hard to explain.

The patterns in Figures $4 \mathrm{a}$ and $4 \mathrm{~b}$ for black and Hispanic students in Texas are somewhat different from those in California. Most importantly, as was noted in the discussion of Table 2, minorities in Texas are less likely to send their scores to the most selective public schools than whites. Another interesting contrast is that the relative rate of SAT-sending between minorities and whites is lower for low-scoring students in Texas, but higher for low-scoring students in California. On the other hand, in Texas as in California there is no indication of a shift in the probability that Hispanic SAT-takers sent their scores to the elite public schools after the end of affirmative action. Moreover, apart from seemingly random fluctuations for the very small $1300+$ test score group, there is no obvious trend in the relative SAT-sending rates of black students in Texas.

To develop more formal evidence on the relative trends in SAT-sending by minorities, we fit a series of linear probability models to the event of sending SAT scores to selective or elite public colleges. The models were estimated separately for SAT takers in California and Texas, and include a long list of individual control variables, including dummies for each ethnicity and each year, and dummies for different ranges of SAT scores, different GPA levels and class ranks, and different levels of parental education. In addition, the models include interactions of year dummies with either a single minority dummy, or interactions with separate dummies for black and Hispanic students. Our main interest is on the interacted time effects, which measure the changes in the probability of sending SAT scores to a particular class of institutions for minorities relative to nonminorities (i.e., the differences-in-differences relative to the base year). An initial set of specifications that include only a single minority indicator interacted with the time effects is presented in Table 4.

Looking first at the results for California in the upper panel of the Table, results for all test 
takers in columns (1) and (5) show a small but statistically significant drop in the relative probability of sending scores to selective or most selective universities between 1997 and 1999. The peak relative impact is $-1.3 \%$ (for the probability of applying to any selective school) and $-1.8 \%$ (for the probability of applying to one of the most selective schools). Between 1999 and 2001, however, the trend is reversed, and the relative year effects for minorities in 2001 are both insignificant, indicating no long run change compared to the base year of 1994. Interestingly, when the sample is restricted to students with higher SAT scores or with relatively good cumulative GPA's, there is no evidence of a dip between 1997 and 1999. Thus, the 1997-99 drop was confined to relatively less-qualified SAT takers. ${ }^{27}$ To summarize the changes associated with ending affirmative action, the table shows the change in the average of the minority relative year effects from 1994-96 to 1999-2001. These are slightly negative for the overall samples but positive (and statistically significant) for the high SAT scorers or the high GPA sample.

The results for Texas also suggest that any effects of ending affirmative action on the SATsending behavior of minority students was small and short-lived. In the case of Texas, however, the only significant difference in the relative year effects arise in the models for high-scoring SAT-takers. Most notable are the effects in column (7) for SAT-sending rates to the most selective public universities by students scoring 1150 or higher on the SAT. Compared to 1995-1997, the relative probability that minorities sent their scores to Texas A\&M or UT Austin fell by 4.4\% in 1998, then gradually recovered. An important caveat is the absence of a similar trend among students with an A or A+ GPA. Since one would expect parallel changes for the high SAT scorers and the high GPA population if there was a true behavioral reaction of highly-qualified minorities to the

\footnotetext{
${ }^{27}$ If we fit the model to SAT-takers with scores under 1000, the peak relative impact is -2.1 percentage points in 1999 (standard error 0.7 points). By 2001 the relative effect for minorities in this sample is very close to 0.
} 
elimination of affirmative action, we are reluctant to draw any strong conclusions from the drop among the high scorers. Morever, the fact that there was no relative drop for lower-scoring minorities leads us to suspect that the drop among high scoring minorities is probably a statistical artifact.

Table 5 presents additional specifications that include separate relative year effects for black and Hispanic test takers, fit to samples of SAT-takers with relatively strong high school records. ${ }^{28}$ (Results for samples with SAT scores above 1150 are similar, but a little noisier). Since the number of highly qualified black applicants is small, the black relative year effects are somewhat variable from year to year. On balance, however, there is no evidence of any fall in the probability that high-GPA minorities sent their scores to selective or most selective public universities after the elimination of affirmative action. In fact, the only significant relative change is for high-GPA Hispanics in California, who were more likely to send their scores to the UC's as a whole, and the most selective UC's in particular, after 1998.

We have also analyzed changes in the relative probability that highly-qualified minority students send their SAT scores only to less selective public institutions (the UC campuses other than Berkeley, Los Angeles, and San Diego, or the Texas schools other than A\&M and Austin). If the elimination of affirmative action causes some highly qualified minorities to lower their sights from most selective to less-selective public colleges one might expect to see a rise in such behavior. In California, using samples of students with SAT scores above 1150, or with at least an "A" average, we find virtually no change in this outcome after 1998. In Texas there is a slight increase in the relative probability that high-SAT minorities sent their scores only to one of the less selective public

\footnotetext{
${ }^{28}$ In an attempt to reduce the sampling errors, these models also include a longer list of individual control variables, although the results are very similar to those obtained from specifications similar to the ones in Table 4.
} 
colleges after 1997 (the change from 1994-1996 to 1999-2001 is +0.014 with a standard error of 0.008), but as in the models in Table 4, this effect appears to be temporary. Comparing 2001 to the 1994-96 average there is no significant change. Also, as in Table 4, the results for high-GPA minorities in Texas are less striking, and show little relative change after 1997 (the change from 1994-1996 to $1999-2001$ is +0.007 with a standard error of 0.008$)$.

\section{e. Other Characteristics of the List of SAT-Receiving Schools}

Finally, we have examined other characteristics of the list of schools that each student designates to receive his or her test scores, including the number of schools in the list, the minimum quality of the institutions in the list (judged by the average SAT of all students who send their scores to each school in the list), and the minority preference of the applicant (measured by the maximum share of minority SAT-senders for the schools on the list). We use national samples of all SAT takers in 1994-1996 to assign these characteristics to each school, and then calculate the relevant statistics over the set of schools in each student's list. ${ }^{29}$ Results for these outcomes are presented in Table 6. The table shows estimates based on samples of high-scoring SAT takers, and based on samples of students with at least an " $\mathrm{A}$ " average in their high school courses.

Looking first at the number of schools designated to receive scores, there is no evidence of a relative change for minorities relative to non-minorities after the end of affirmative action. Focusing next on the minimum average quality of the institutions selected by each student, there are again no large or significant changes in the behavior of highly qualified minorities relative to their nonminority counterparts. In particular, highly qualified minorities did not seem to be adding lower-

\footnotetext{
${ }^{29}$ Average SAT's of applicants to a school are highly correlated with data on average SAT's of entering freshmen, reported in Barron's Guide.
} 
quality "safety schools" to the list of institutions receiving their test scores in the post affirmative action era. The strongest results in Table 6 pertain to the maximum minority share. On balance there is a slight shift of high-achievement minority students away from high-minority schools, contrary to what might have been expected. We also fit models for the average quality and average minority share of the schools on each students' list of SAT-receiving institutions. Neither of these outcomes shows a significant relative change for highly qualified minorities relative to comparable non-minorities. Taken as a whole, we believe the results in Tables 4-6 support the conclusion that the elimination of affirmative action had little or no effect on the application behavior of highly qualified minority students in California or Texas.

\section{Summary}

The case for preserving or eliminating affirmative action depends on many factors. One issue is whether the elimination of racial preferences in college admission would indirectly harm the educational outcomes of highly qualified minorities by diverting the most able black and Hispanic students away from elite colleges and universities. In this paper we use the recent experiences in California and Texas to analyze the effects of ending affirmative action on the critical first step of the college choice process - the decision of where to apply. We use a simple difference-indifferences research design to measure relative changes in the probability that minority SAT-takers sent their test results to selective public institutions after affirmative action was ended in the two states. Changes in the number of students who send SAT scores to a given institution are very highly correlated with changes in the number who actually apply, and we have little reason to doubt that changes in the probability of sending SAT scores to selective public colleges accurately reflect changes in the probability of applying to these colleges. 
Our most important finding is that the elimination of race-based admissions preferences in California and Texas had little or no effect on the decisions of highly qualified minorities to submit their SAT scores (and presumably apply) to the selective institutions in the two states. This is true irrespective of whether we use SAT scores or high school grades to define highly qualified candidates. It is also true whether we focus on minority students generally or treat black and Hispanic students separately. Moreover, the end of affirmative action had little relative impact on other characteristics of the list of schools designated by minority test-taker to receive their scores. In particular, we find no tendency for highly qualified minorities to lower their sights after affirmative action was ended by adding a low quality school to their list of receiving schools, or to refocus their search on institutions with a higher fraction of minority applicants.

Our empirical results suggest that the application decisions of highly qualified minority students are not very sensitive to changes in the racial and ethnic composition of the student bodies at selective public colleges and universities caused by ending affirmative action. The data do not allow us to tell whether this is because minority students are relatively unconcerned about the broad demographic characteristics of their potential peer group, or because any such concerns are outweighed by the advantages of attending more selective institutions. It is also possible that outreach and information programs at the selective state institutions have prevented large negative impacts of the less diverse campus environment. At a minimum, however, fear that ending affirmative action would cause a diversion of highly qualified minority students away from the elite colleges and universities appear to be unfounded. 


\section{References}

Ashenfelter, Orley. "Estimating the Effect of Training Programs on Earnings." Review of Economics and Statistics 6 (February 1978): 47-57.

Bowen, William G. and Derek Bok. The Shape of the River: Long Term Consequences of Considering Race in College and University Admissions. Princeton, NJ: Princeton University Press, 1998.

Brewer, Dominic, Eric Eide, and Ronald G. Ehrenberg. "Does it Pay to Attend an Elite College? Cross-Cohort Evidence on the Effects of College Type on Earnings." Journal of Human Resources 34 (Winter 1999): 104-123.

Bucks, Brian. “Affirmative Access Versus Affirmative Action: How Have Texas' Race-Blind Policies Affected College Outcomes?" Unpublished Working Paper, University of Texas at Dallas Green Center for the Study of Science and Society, February 2003.

Clark, Melissa A. "Selection Bias in College Admissions Test Data." Unpublished Manuscript, Princeton University Department of Economics, May 2003.

Dale, Stacy Berg and Alan B. Krueger. "Estimating the Payoff to Attending a More Selective College: An Application of Selection on Observables and Unobservables." Quarterly Journal of Economics 117 (November 2002): 1491-1528.

Fuller, Winship C., Charles F. Manski, and David A. Wise. "New Evidence on the Economic Determinants of Postsecondary Schooling Choices." Journal of Human Resources 17 (1982): 477-498.

Kane, Thomas J. "Racial and Ethnic Preferences in College Admissions." In Christopher Jencks and Meredith Phillips, editors, The Black-White Test Score Gap. Washington DC: Brookings Institution Press, 1998.

Kohn, Meier G., Charles F. Manski, and David S. Mundel. “An Empirical Investigation of Factors Influencing College Going Behavior.” Annals of Economic and Social Measurement 5 (Fall 1976): 391 419.

Long, Mark. "College Applications and the Effect of Affirmative Action." George Washington University Department of Economics Unpublished Working Paper, August 2002.

National Association for College Admission Counseling. "Affirmative Action in College Admission”. Issue Paper, Summer 2001. Washington, DC: National Association for College Admission Counseling, 2001.

Rothstein, Jesse M. "College Performance Predictions and the SAT." Journal of Economctrics, forthcoming 2003. 
Schotter, Andrew and Keith Weigelt. "Asymmetric Tournaments, Equal Opportunity Laws, and Affirmative Action: Some Experimental Results.” Quarterly Journal of Economics 107 (May 1992): 511 539.

Sharp, John. Disparity in Texas Higher Education: Recruitment, Admissions, Retention, and Financial Aid. (Volume 1 and Volume 2). Austin Texas: Texas Comptroller of Public Accounts, 1999.

Society for Industrial and Organizational Psychology. "Psychological and Behavioral Effects of Affirmative Action on Target Group Members." Undated manuscript. Available at http://siop.org/AfirmAct/siopsaartarg.htm .

Steele, Claude M. and Joshua Aronson. "Stereotype Threat and the Test Performance of Academically Successful African Americans." In Christopher Jencks and Meredith Phillips, editors, The Black-White Test Score Gap. Washington DC: Brookings Institution Press, 1998.

Texas Higher Education Coordinating Board. "First Time Undergraduate Applicant, Acceptance, and Enrollment Information for Summer/Fall 1998-2001." Austin, Texas: Texas Higher Education Coordinating Board. Available at http://www.thecb.state.tx.us/reports/.

Thomas, M. Kathleen. "Where College Bound Texas Students Send Their SAT and ACT Scores: Does Race Matter?" Unpublished Manuscript, University of Texas at Dallas Green Center for the Study of Science and Society, February 2002.

Tienda, Marta, Kevin T. Leicht, Teresa Sullivan, Michael Maltese, and Kim Lloyd. "Closing the Gap?: Admissions and Enrollments at the Texas Public Flagships Before and After Affirmative Action.” Princeton University Department of Sociology Unpublished Working Paper, January 2003. Available at http://www.texastop10.princeton.edu/publications/tienda012103.pdf.

Turner, M.E. and A. R. Pratkanis. "Affirmative Action as Help: A Review of Recipient Reactions to Preferential Selection and Affirmative Action.” Basic and Applied Psychology 15 (1994): 43-69.

University of California Office of the President. Information Digest, 1998. Oakland California: University of California Office of the President. Available at http://www.ucop.edu/sas/infodigest/.

University of California Office of the President. "University of California Applications, Admissions, and Enrollment of California Resident Freshmen for Fall 1995 Through 2002.” (2003). Available at http://www.ucop.edu/news/factsheets/flowfrc9502.pdf. 
Appendix Table 1: Summary of SAT Data Set by State and Year

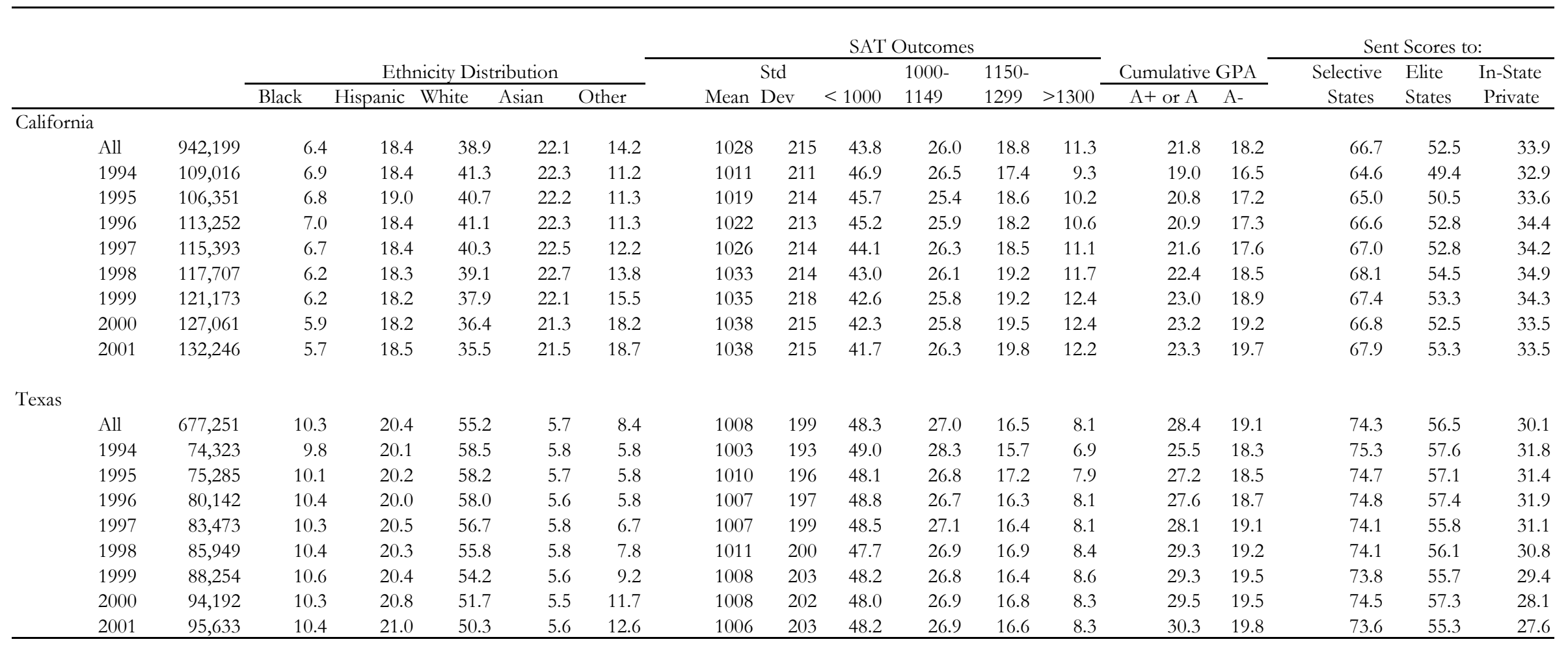

Note: Samples include all SAT from the given entry cohort who designate at least one institution to receive their scores. "Other" ethnicity includes American Indians and those who decline to state their ethnicity. SAT scores are "re-centered" scores. Selective state schools include all schools listed in Table 1. Elite state schools include Berkeley, UCLA and UC San Diego (for California test-takers) and Texas A\&M and UT Austin (for Texas test-takers). In-state private schools are listed in text. 
Table 1: Characteristics of Freshman Applicants, Admittees, Enrollees, and SAT-takers in 1995

\begin{tabular}{|c|c|c|c|c|c|c|c|c|c|c|c|c|}
\hline & \multicolumn{7}{|c|}{ Administrative Data } & \multicolumn{5}{|c|}{ Data from SAT-Takers Who Sent Scores: } \\
\hline & \multirow{2}{*}{$\begin{array}{l}\text { Number } \\
\text { Applicants } \\
\text { (1) }\end{array}$} & \multirow{2}{*}{$\begin{array}{l}\text { Percent } \\
\text { Minority } \\
\text { (2) }\end{array}$} & \multicolumn{2}{|c|}{ Admission Rates: } & \multicolumn{2}{|c|}{ Yield Rates: } & \multirow{2}{*}{$\begin{array}{c}\text { Enrollee } \\
\text { Pct Minority } \\
(7)\end{array}$} & \multirow{2}{*}{$\begin{array}{c}\text { Pct. } \\
\text { Minority } \\
(8)\end{array}$} & \multicolumn{2}{|c|}{ Average SAT: } & \multicolumn{2}{|c|}{ GPA A- or Better: } \\
\hline & & & $\begin{array}{c}\text { All } \\
\text { (3) }\end{array}$ & $\begin{array}{c}\text { Minorities } \\
\text { (4) }\end{array}$ & $\begin{array}{l}\text { All } \\
(5) \\
\end{array}$ & $\begin{array}{c}\text { Minorities } \\
(6)\end{array}$ & & & $\begin{array}{r}\text { All } \\
(9) \\
\end{array}$ & $\begin{array}{c}\text { Minorities } \\
(10)\end{array}$ & $\begin{array}{l}\text { All } \\
(11) \\
\end{array}$ & $\begin{array}{c}\text { Minorities } \\
(12)\end{array}$ \\
\hline \multicolumn{13}{|l|}{ California } \\
\hline$\overline{\text { UCLA }}$ & 23,002 & 22.1 & 43.1 & 52.1 & 35.5 & 39.5 & 29.9 & 23.4 & 1,105 & 954 & 57.6 & 40.1 \\
\hline San Diego & 20,085 & 15.5 & 59.5 & 52.6 & 24.7 & 19.1 & 10.6 & 16.8 & 1,126 & 979 & 57.6 & 41.5 \\
\hline Berkeley & 19,458 & 19.2 & 39.9 & 53.6 & 39.0 & 35.8 & 23.6 & 18.8 & 1,155 & 1,003 & 64.8 & 47.6 \\
\hline Santa Barbara & 17,047 & 18.8 & 81.7 & 75.1 & 23.1 & 22.5 & 16.8 & 17.5 & 1,090 & 967 & 48.2 & 37.5 \\
\hline Davis & 16,718 & 15.3 & 71.8 & 81.0 & 26.4 & 19.1 & 16.5 & 14.3 & 1,109 & 987 & 56.8 & 44.1 \\
\hline Irvine & 15,075 & 19.8 & 74.3 & 68.7 & 25.5 & 21.3 & 15.2 & 17.2 & 1,080 & 955 & 51.3 & 39.4 \\
\hline Santa Cruz & 10,328 & 21.7 & 85.1 & 86.1 & 19.2 & 18.4 & 21.0 & 17.9 & 1,086 & 960 & 43.8 & 33.7 \\
\hline Riverside & 9,341 & 24.7 & 79.5 & 77.6 & 20.9 & 24.9 & 28.7 & 23.1 & 1,036 & 923 & 43.8 & 34.0 \\
\hline \multicolumn{13}{|l|}{ Texas } \\
\hline$\overline{\mathrm{UT}}$ Austin & 12,350 & 19.7 & 94.1 & 97.8 & 47.6 & 41.7 & 19.5 & 26.2 & 1,077 & 967 & 56.8 & 46.9 \\
\hline Texas A\&M & 11,561 & 15.1 & 74.2 & 89.0 & 57.1 & 51.0 & 19.6 & 20.7 & 1,063 & 965 & 57.8 & 46.6 \\
\hline Texas Tech & 7,286 & 18.5 & 100.0 & 100.0 & 45.8 & 38.2 & 14.6 & 19.9 & 1,014 & 911 & 48.8 & 37.3 \\
\hline Southwest Texas & 6,660 & 30.3 & 75.8 & 68.5 & 56.8 & 52.0 & 22.8 & 26.5 & 967 & 885 & 39.4 & 31.4 \\
\hline Univ. Houston & 6,283 & 48.6 & 96.6 & 94.5 & 63.0 & 61.5 & 36.3 & 40.4 & 982 & 898 & 39.5 & 31.6 \\
\hline Univ. North Texas & 5,250 & 27.1 & 76.5 & 64.5 & 52.8 & 49.5 & 16.7 & 23.2 & 1,007 & 899 & 44.9 & 16.7 \\
\hline
\end{tabular}

Notes: See text for sources. Administrative data for California pertain to the Fall 1995 freshman cohort of California residents.

Texas admission and yield rates are based on data by ethnicity for 1995 first time freshman reported in Sharp (1999). Number of applicants and ethnic mix

of Texas applicants is based on data for Fall 1998 first time Texas undergraduate applicants. 
Table 2: Characteristics of SAT Takers by State and Ethnicity, Before and After the Elimination of Affirmative Action

\begin{tabular}{|c|c|c|c|c|c|c|c|c|c|c|c|c|c|}
\hline & \multirow{3}{*}{$\begin{array}{c}\text { Number } \\
\text { Observations }\end{array}$} & \multicolumn{4}{|c|}{ SAT Outcomes: } & & & \multicolumn{2}{|c|}{ Class Rank: } & \multicolumn{4}{|c|}{ SAT Scores Sent to: } \\
\hline & & \multirow[b]{2}{*}{ Mean } & \multirow[b]{2}{*}{$<1150$} & \multirow{2}{*}{$\begin{array}{l}1150- \\
1299\end{array}$} & \multirow[b]{2}{*}{$>1300$} & \multicolumn{2}{|c|}{ Cumulative GPA: } & \multirow{2}{*}{$\begin{array}{c}\text { Top } \\
\text { Decile }\end{array}$} & \multirow{2}{*}{$\begin{array}{c}\text { 2nd } \\
\text { Decile }\end{array}$} & \multirow{2}{*}{$\begin{array}{c}\text { Mean } \\
\text { \# Schools }\end{array}$} & \multirow{2}{*}{$\begin{array}{l}\text { Selective } \\
\text { Publics }\end{array}$} & \multirow{2}{*}{$\begin{array}{c}\text { Most } \\
\text { Selective }\end{array}$} & \multirow{2}{*}{$\begin{array}{l}\text { In-State } \\
\text { Privates }\end{array}$} \\
\hline & & & & & & $\mathrm{A}+/ \mathrm{A}$ & A- & & & & & & \\
\hline \multicolumn{14}{|c|}{ California } \\
\hline \multicolumn{14}{|c|}{ Black Non-Hispanic } \\
\hline 1994-1996 & 22,646 & 862 & 92.5 & 6.0 & 1.5 & 7.4 & 8.5 & 9.0 & 17.2 & 5.6 & 50.8 & 41.8 & 30.9 \\
\hline 1999-2001 & 22,600 & 877 & 90.7 & 7.2 & 2.1 & 9.8 & 11.3 & 11.5 & 19.9 & 5.8 & 51.6 & 41.8 & 31.8 \\
\hline \multicolumn{14}{|l|}{ Hispanic } \\
\hline 1994-1996 & 61,093 & 902 & 89.1 & 8.5 & 2.4 & 12.9 & 13.2 & 13.8 & 20.3 & 5.3 & 63.5 & 49.5 & 36.1 \\
\hline 1999-2001 & 69,694 & 907 & 88.7 & 8.6 & 2.7 & 15.6 & 15.3 & 16.3 & 23.3 & 5.4 & 63.8 & 49.7 & 33.6 \\
\hline \multicolumn{14}{|c|}{ White Non-Hispanic } \\
\hline 1994-1996 & 134,796 & 1081 & 63.6 & 23.9 & 12.5 & 22.9 & 19.3 & 24.0 & 24.4 & 5.7 & 60.5 & 42.7 & 28.4 \\
\hline 1999-2001 & 139,154 & 1103 & 58.8 & 25.9 & 15.3 & 26.8 & 21.8 & 29.4 & 27.4 & 5.8 & 63.5 & 46.8 & 31.1 \\
\hline \multicolumn{14}{|l|}{ Asian } \\
\hline 1994-1996 & 73,103 & 1039 & 68.0 & 18.4 & 13.5 & 27.7 & 20.6 & 24.7 & 24.4 & 6.5 & 82.0 & 70.8 & 42.3 \\
\hline 1999-2001 & 82,383 & 1060 & 64.0 & 19.8 & 16.2 & 28.9 & 22.2 & 27.5 & 25.7 & 6.5 & 83.5 & 71.3 & 39.0 \\
\hline \multicolumn{14}{|l|}{ Texas } \\
\hline \multicolumn{14}{|c|}{ Black Non-Hispanic } \\
\hline 1994-1996 & 23,266 & 860 & 94.2 & 4.8 & 1.0 & 12.0 & 12.8 & 11.8 & 18.9 & 5.0 & 59.1 & 35.7 & 26.2 \\
\hline 1999-2001 & 29,028 & 859 & 93.6 & 5.2 & 1.2 & 14.5 & 13.9 & 12.8 & 20.3 & 5.1 & 64.2 & 36.5 & 24.7 \\
\hline \multicolumn{14}{|l|}{$\underline{\text { Hispanic }}$} \\
\hline 1994-1996 & 46,170 & 922 & 89.3 & 8.3 & 2.4 & 20.6 & 17.1 & 17.6 & 20.0 & 4.9 & 68.8 & 51.6 & 31.3 \\
\hline 1999-2001 & 57,652 & 911 & 89.6 & 8.0 & 2.4 & 23.1 & 18.7 & 19.1 & 20.9 & 4.8 & 66.1 & 49.0 & 25.8 \\
\hline \multicolumn{14}{|c|}{ White Non-Hispanic } \\
\hline 1994-1996 & 133,864 & 1055 & 69.6 & 20.8 & 9.6 & 31.3 & 20.3 & 24.7 & 22.9 & 4.9 & 79.3 & 61.9 & 31.1 \\
\hline 1999-2001 & 144,664 & 1063 & 67.8 & 21.6 & 10.6 & 35.5 & 21.5 & 26.9 & 25.2 & 4.8 & 78.1 & 61.1 & 28.8 \\
\hline \multicolumn{14}{|l|}{ Asian } \\
\hline 1994-1996 & 13,101 & 1074 & 62.5 & 20.4 & 17.1 & 39.0 & 21.6 & 32.9 & 22.9 & 6.0 & 85.6 & 75.7 & 53.9 \\
\hline 1999-2001 & 15,485 & 1087 & 60.4 & 21.0 & 18.6 & 39.6 & 23.4 & 36.0 & 24.4 & 5.7 & 87.1 & 76.4 & 46.7 \\
\hline
\end{tabular}

Notes: Samples include SAT takers who selected at least one college to receive their scores. Year refers to college entry cohort: students in the 1994 cohort may have taken the SAT in 1992, 1993, or 1994. SAT scores are recentered. GPA and class rank are based on student self-reports. Schools included as selective publics, most selective publics, and in-state privates are described in text. 
Table 3: Partial Correlation Between Number of SAT-Takers and Number of Applicants

\begin{tabular}{|c|c|c|c|c|}
\hline & \multicolumn{2}{|c|}{ All 8 UC Campuses } & \multicolumn{2}{|c|}{3 Elite Campuses } \\
\hline & $(1)$ & (2) & (3) & (4) \\
\hline Log Number of Applicants & $\begin{array}{r}0.95 \\
(0.03)\end{array}$ & $\begin{array}{r}0.48 \\
(0.05)\end{array}$ & $\begin{array}{r}0.96 \\
(0.06)\end{array}$ & $\begin{array}{r}0.74 \\
(0.13)\end{array}$ \\
\hline Campus \& Year*Ethnicity Effects? & Yes & Yes & Yes & Yes \\
\hline $\begin{array}{l}\text { Campus*Ethnicity \& } \\
\text { Campus*Year Effects? }\end{array}$ & No & Yes & No & Yes \\
\hline R-Squared & 0.994 & 0.999 & 0.990 & 0.999 \\
\hline Root Mean Squared Error & 0.085 & 0.030 & 0.110 & 0.030 \\
\hline
\end{tabular}

Notes: Entries are regression coefficients and standard errors from regressions of the log of the number of SAT-takers who send their scores to a particular campus (by ethnicity and year) on the log of the number of applications actually received by the campus, and the other dummies indicated. Sample include: observations from 1995 to 2001 for 4 ethnic groups (white non-Hispanic, Asian, Black, and Hispanic). 
Table 4: Changes in Relative Probability that Minority Students Send SAT Scores to Selective and Most Selective State Universities

\begin{tabular}{|c|c|c|c|c|c|c|c|c|}
\hline & \multicolumn{4}{|c|}{ Send to Selective State Universities } & \multicolumn{4}{|c|}{ Send to Most Selective State Universities } \\
\hline & $\begin{array}{l}\text { All } \\
(1) \\
\end{array}$ & $\begin{array}{c}\text { SAT }>1000 \\
(2)\end{array}$ & $\begin{array}{c}\mathrm{SAT}>1150 \\
(3)\end{array}$ & $\begin{array}{c}\mathrm{A} / \mathrm{A}+\mathrm{gpa} \\
(4) \\
\end{array}$ & $\begin{array}{l}\text { All } \\
(5) \\
\end{array}$ & $\begin{array}{c}\text { SAT }>1000 \\
(6)\end{array}$ & $\begin{array}{c}\mathrm{SAT}>1150 \\
(7)\end{array}$ & $\begin{array}{c}\mathrm{A} / \mathrm{A}+\mathrm{gpa} \\
(8) \\
\end{array}$ \\
\hline \multicolumn{9}{|c|}{ Part A: California SAT Takers } \\
\hline 1995 & $\begin{array}{r}0.011 \\
(0.005)\end{array}$ & $\begin{array}{r}0.008 \\
(0.007)\end{array}$ & $\begin{array}{r}0.019 \\
(0.011)\end{array}$ & $\begin{array}{r}0.021 \\
(0.010)\end{array}$ & $\begin{array}{r}0.010 \\
(0.005)\end{array}$ & $\begin{array}{r}0.008 \\
(0.008)\end{array}$ & $\begin{array}{r}0.025 \\
(0.012)\end{array}$ & $\begin{array}{r}0.023 \\
(0.012)\end{array}$ \\
\hline 1996 & $\begin{array}{r}0.002 \\
(0.004)\end{array}$ & $\begin{array}{r}0.011 \\
(0.007)\end{array}$ & $\begin{array}{r}0.030 \\
(0.010)\end{array}$ & $\begin{array}{r}0.027 \\
(0.010)\end{array}$ & $\begin{array}{r}-0.001 \\
(0.004)\end{array}$ & $\begin{array}{r}0.008 \\
(0.007)\end{array}$ & $\begin{array}{r}0.036 \\
(0.012)\end{array}$ & $\begin{array}{r}0.030 \\
(0.011)\end{array}$ \\
\hline 1997 & $\begin{array}{l}-0.006 \\
(0.004)\end{array}$ & $\begin{array}{l}-0.002 \\
(0.007)\end{array}$ & $\begin{array}{r}0.030 \\
(0.010)\end{array}$ & $\begin{array}{r}0.028 \\
(0.009)\end{array}$ & $\begin{array}{l}-0.006 \\
(0.004)\end{array}$ & $\begin{array}{l}-0.008 \\
(0.007)\end{array}$ & $\begin{array}{r}0.030 \\
(0.012)\end{array}$ & $\begin{array}{r}0.037 \\
(0.011)\end{array}$ \\
\hline 1998 & $\begin{array}{r}-0.009 \\
(0.004)\end{array}$ & $\begin{array}{l}-0.009 \\
(0.007)\end{array}$ & $\begin{array}{r}0.005 \\
(0.010)\end{array}$ & $\begin{array}{r}0.025 \\
(0.009)\end{array}$ & $\begin{array}{r}-0.010 \\
(0.004)\end{array}$ & $\begin{array}{r}-0.011 \\
(0.007)\end{array}$ & $\begin{array}{r}0.004 \\
(0.012)\end{array}$ & $\begin{array}{r}0.029 \\
(0.011)\end{array}$ \\
\hline 1999 & $\begin{array}{r}-0.013 \\
(0.004)\end{array}$ & $\begin{array}{r}0.001 \\
(0.007)\end{array}$ & $\begin{array}{r}0.022 \\
(0.010)\end{array}$ & $\begin{array}{r}0.032 \\
(0.009)\end{array}$ & $\begin{array}{r}-0.018 \\
(0.005)\end{array}$ & $\begin{array}{r}-0.015 \\
(0.008)\end{array}$ & $\begin{array}{r}0.022 \\
(0.012)\end{array}$ & $\begin{array}{r}0.026 \\
(0.011)\end{array}$ \\
\hline 2000 & $\begin{array}{r}-0.004 \\
(0.004)\end{array}$ & $\begin{array}{r}0.000 \\
(0.007)\end{array}$ & $\begin{array}{r}0.027 \\
(0.010)\end{array}$ & $\begin{array}{r}0.033 \\
(0.009)\end{array}$ & $\begin{array}{r}-0.010 \\
(0.005)\end{array}$ & $\begin{array}{r}-0.009 \\
(0.008)\end{array}$ & $\begin{array}{r}0.034 \\
(0.012)\end{array}$ & $\begin{array}{r}0.039 \\
(0.011)\end{array}$ \\
\hline 2001 & $\begin{array}{l}-0.001 \\
(0.005)\end{array}$ & $\begin{array}{r}0.011 \\
(0.007)\end{array}$ & $\begin{array}{r}0.027 \\
(0.010)\end{array}$ & $\begin{array}{r}0.036 \\
(0.009)\end{array}$ & $\begin{array}{r}-0.008 \\
(0.005)\end{array}$ & $\begin{array}{r}0.002 \\
(0.008)\end{array}$ & $\begin{array}{r}0.034 \\
(0.012)\end{array}$ & $\begin{array}{r}0.045 \\
(0.011)\end{array}$ \\
\hline Average & $999-2001$ & - Average (1 & 994-1996) & & & & & \\
\hline $\begin{array}{l}\text { Estimate } \\
\text { (std err) }\end{array}$ & $\begin{array}{l}-0.010 \\
(0.003)\end{array}$ & $\begin{array}{r}-0.002 \\
(0.005)\end{array}$ & $\begin{array}{r}0.009 \\
(0.008)\end{array}$ & $\begin{array}{r}0.018 \\
(0.007)\end{array}$ & $\begin{array}{l}-0.015 \\
(0.003)\end{array}$ & $\begin{array}{l}-0.013 \\
(0.006)\end{array}$ & $\begin{array}{r}0.010 \\
(0.009)\end{array}$ & $\begin{array}{r}0.019 \\
(0.008)\end{array}$ \\
\hline Part B: Te & zas SAT & Takers & & & & & & \\
\hline 1995 & $\begin{array}{r}0.013 \\
(0.005)\end{array}$ & $\begin{array}{r}0.003 \\
(0.008)\end{array}$ & $\begin{array}{r}0.000 \\
(0.013)\end{array}$ & $\begin{array}{l}-0.008 \\
(0.010)\end{array}$ & $\begin{array}{r}0.014 \\
(0.006)\end{array}$ & $\begin{array}{r}0.002 \\
(0.009)\end{array}$ & $\begin{array}{l}-0.021 \\
(0.015)\end{array}$ & $\begin{array}{l}-0.005 \\
(0.012)\end{array}$ \\
\hline 1996 & $\begin{array}{r}0.009 \\
(0.005)\end{array}$ & $\begin{array}{r}0.001 \\
(0.007)\end{array}$ & $\begin{array}{l}-0.005 \\
(0.012)\end{array}$ & $\begin{array}{r}0.005 \\
(0.010)\end{array}$ & $\begin{array}{r}0.016 \\
(0.005)\end{array}$ & $\begin{array}{r}0.002 \\
(0.009)\end{array}$ & $\begin{array}{r}-0.020 \\
(0.014)\end{array}$ & $\begin{array}{r}0.012 \\
(0.011)\end{array}$ \\
\hline 1997 & $\begin{array}{r}0.011 \\
(0.005)\end{array}$ & $\begin{array}{r}0.004 \\
(0.007)\end{array}$ & $\begin{array}{r}0.003 \\
(0.012)\end{array}$ & $\begin{array}{r}0.001 \\
(0.010)\end{array}$ & $\begin{array}{r}0.003 \\
(0.005)\end{array}$ & $\begin{array}{r}-0.011 \\
(0.009)\end{array}$ & $\begin{array}{r}-0.020 \\
(0.014)\end{array}$ & $\begin{array}{r}-0.014 \\
(0.011)\end{array}$ \\
\hline 1998 & $\begin{array}{r}0.016 \\
(0.005)\end{array}$ & $\begin{array}{r}-0.008 \\
(0.007)\end{array}$ & $\begin{array}{l}-0.021 \\
(0.012)\end{array}$ & $\begin{array}{r}-0.004 \\
(0.009)\end{array}$ & $\begin{array}{r}0.006 \\
(0.005)\end{array}$ & $\begin{array}{r}-0.022 \\
(0.008)\end{array}$ & $\begin{array}{r}-0.044 \\
(0.014)\end{array}$ & $\begin{array}{r}-0.020 \\
(0.011)\end{array}$ \\
\hline 1999 & $\begin{array}{r}0.018 \\
(0.005)\end{array}$ & $\begin{array}{r}-0.008 \\
(0.007)\end{array}$ & $\begin{array}{r}-0.016 \\
(0.012)\end{array}$ & $\begin{array}{r}-0.012 \\
(0.010)\end{array}$ & $\begin{array}{r}0.007 \\
(0.005)\end{array}$ & $\begin{array}{r}-0.020 \\
(0.009)\end{array}$ & $\begin{array}{r}-0.035 \\
(0.014)\end{array}$ & $\begin{array}{l}-0.013 \\
(0.011)\end{array}$ \\
\hline 2000 & $\begin{array}{r}0.019 \\
(0.005)\end{array}$ & $\begin{array}{r}0.001 \\
(0.007)\end{array}$ & $\begin{array}{r}0.006 \\
(0.012)\end{array}$ & $\begin{array}{r}0.003 \\
(0.009)\end{array}$ & $\begin{array}{r}0.005 \\
(0.005)\end{array}$ & $\begin{array}{r}-0.021 \\
(0.009)\end{array}$ & $\begin{array}{r}-0.028 \\
(0.014)\end{array}$ & $\begin{array}{r}-0.004 \\
(0.011)\end{array}$ \\
\hline 2001 & $\begin{array}{r}0.024 \\
(0.005)\end{array}$ & $\begin{array}{r}0.013 \\
(0.007)\end{array}$ & $\begin{array}{r}0.003 \\
(0.012)\end{array}$ & $\begin{array}{l}-0.001 \\
(0.009)\end{array}$ & $\begin{array}{r}0.021 \\
(0.005)\end{array}$ & $\begin{array}{r}0.002 \\
(0.009)\end{array}$ & $\begin{array}{l}-0.021 \\
(0.014)\end{array}$ & $\begin{array}{l}-0.006 \\
(0.011)\end{array}$ \\
\hline Average ( & $999-2001$ & - Average (1 & 994-1996) & & & & & \\
\hline $\begin{array}{l}\text { Estimate } \\
\text { (std err) }\end{array}$ & $\begin{array}{r}0.013 \\
(0.004)\end{array}$ & $\begin{array}{r}0.001 \\
(0.006)\end{array}$ & $\begin{array}{r}0.000 \\
(0.009)\end{array}$ & $\begin{array}{r}-0.003 \\
(0.007)\end{array}$ & $\begin{array}{r}0.001 \\
(0.004)\end{array}$ & $\begin{array}{r}-0.014 \\
(0.006)\end{array}$ & $\begin{array}{r}-0.014 \\
(0.011)\end{array}$ & $\begin{array}{r}-0.010 \\
(0.008)\end{array}$ \\
\hline
\end{tabular}

Note: Table shows estimates (and standard errors) of interaction of year dummies and minority (Black or Hispanic) ethnicity in linear probability models for the event of sending SAT scores to selective state universities (columns 1-4) or most selective state universities (columns 5-8). All models also include year effects, ethnicity effects, and controls for parents' education, SAT range, cumulative GPA, rank in high school class, and grade when test written. 
Table 5: Additional Specifications for Black and Hispanic Students with A or A- GPA

\begin{tabular}{|c|c|c|c|c|c|c|c|c|}
\hline & \multicolumn{4}{|c|}{ California SAT Takers: } & \multicolumn{4}{|c|}{ Texas SAT Takers: } \\
\hline & \multicolumn{2}{|c|}{ Selective: } & \multicolumn{2}{|c|}{ Most Selective: } & \multicolumn{2}{|c|}{ Selective: } & \multicolumn{2}{|c|}{ Most Selective: } \\
\hline & Black I & Hispanic & Black & Hispanic & Black & Hispanic & Black & Hispanic \\
\hline 1995 & $\begin{array}{r}0.069 \\
(0.022)\end{array}$ & $\begin{array}{r}0.012 \\
(0.011)\end{array}$ & $\begin{array}{r}0.056 \\
(0.026)\end{array}$ & $\begin{array}{r}0.017 \\
(0.013)\end{array}$ & $\begin{array}{c}-0.007 \\
(0.020)\end{array}$ & $\begin{array}{r}-0.010 \\
(0.011)\end{array}$ & $\begin{array}{r}0.022 \\
(0.023)\end{array}$ & $\begin{array}{l}-0.015 \\
(0.013)\end{array}$ \\
\hline 1996 & $\begin{array}{r}0.064 \\
(0.021)\end{array}$ & $\begin{array}{r}0.022 \\
(0.010)\end{array}$ & $\begin{array}{r}0.081 \\
(0.025)\end{array}$ & $\begin{array}{r}0.023 \\
(0.012)\end{array}$ & $\begin{array}{r}0.025 \\
(0.019)\end{array}$ & $\begin{array}{r}0.000 \\
(0.011)\end{array}$ & $\begin{array}{r}0.032 \\
(0.022)\end{array}$ & $\begin{array}{r}0.009 \\
(0.012)\end{array}$ \\
\hline 1997 & $\begin{array}{r}0.013 \\
(0.021)\end{array}$ & $\begin{array}{r}0.032 \\
(0.010)\end{array}$ & $\begin{array}{r}0.026 \\
(0.025)\end{array}$ & $\begin{array}{r}0.041 \\
(0.012)\end{array}$ & $\begin{array}{r}0.017 \\
(0.018)\end{array}$ & $\begin{array}{c}-0.002 \\
(0.011)\end{array}$ & $\begin{array}{r}-0.010 \\
(0.021)\end{array}$ & $\begin{array}{l}-0.012 \\
(0.012)\end{array}$ \\
\hline 1998 & $\begin{array}{r}0.045 \\
(0.021)\end{array}$ & $\begin{array}{r}0.024 \\
(0.010)\end{array}$ & $\begin{array}{r}0.060 \\
(0.024)\end{array}$ & $\begin{array}{r}0.026 \\
(0.011)\end{array}$ & $\begin{array}{r}0.010 \\
(0.018)\end{array}$ & $\begin{array}{c}-0.005 \\
(0.011)\end{array}$ & $\begin{array}{l}-0.013 \\
(0.021)\end{array}$ & $\begin{array}{r}-0.018 \\
(0.012)\end{array}$ \\
\hline 1999 & $\begin{array}{r}0.024 \\
(0.021)\end{array}$ & $\begin{array}{r}0.034 \\
(0.010)\end{array}$ & $\begin{array}{r}0.005 \\
(0.025)\end{array}$ & $\begin{array}{r}0.031 \\
(0.012)\end{array}$ & $\begin{array}{r}0.032 \\
(0.018)\end{array}$ & $\begin{array}{c}-0.025 \\
(0.011)\end{array}$ & $\begin{array}{r}0.004 \\
(0.021)\end{array}$ & $\begin{array}{l}-0.016 \\
(0.012)\end{array}$ \\
\hline 2000 & $\begin{array}{r}0.048 \\
(0.021)\end{array}$ & $\begin{array}{r}0.030 \\
(0.010)\end{array}$ & $\begin{array}{r}0.054 \\
(0.025)\end{array}$ & $\begin{array}{r}0.036 \\
(0.012)\end{array}$ & $\begin{array}{r}0.038 \\
(0.018)\end{array}$ & $\begin{array}{c}-0.007 \\
(0.011)\end{array}$ & $\begin{array}{r}0.029 \\
(0.021)\end{array}$ & $\begin{array}{l}-0.012 \\
(0.012)\end{array}$ \\
\hline 2001 & $\begin{array}{r}0.043 \\
(0.021)\end{array}$ & $\begin{array}{r}0.034 \\
(0.010)\end{array}$ & $\begin{array}{r}0.030 \\
(0.025)\end{array}$ & $\begin{array}{r}0.047 \\
(0.011)\end{array}$ & $\begin{array}{r}0.020 \\
(0.018)\end{array}$ & $\begin{array}{r}-0.010 \\
(0.010)\end{array}$ & $\begin{array}{r}-0.016 \\
(0.021)\end{array}$ & $\begin{array}{r}-0.001 \\
(0.012)\end{array}$ \\
\hline $\begin{array}{l}\text { Average (19) } \\
\text { Estimate } \\
\text { (Std Error) }\end{array}$ & $\begin{array}{c}2001)-A \\
-0.006 \\
(0.016)\end{array}$ & $\begin{array}{c}\text { verage }(199 \\
0.021 \\
(0.008)\end{array}$ & $\begin{array}{r}\frac{4-1996)}{-0.016} \\
(0.019)\end{array}$ & $\begin{array}{r}0.025 \\
(0.009)\end{array}$ & $\begin{array}{r}0.024 \\
(0.014)\end{array}$ & $\begin{array}{c}-0.011 \\
(0.008)\end{array}$ & $\begin{array}{r}-0.012 \\
(0.016)\end{array}$ & $\begin{array}{r}-0.008 \\
(0.009)\end{array}$ \\
\hline
\end{tabular}

Notes: See notes to Table 4. Models are estimated on samples of SAT takers with A- or better GPA. 
Table 6: Relative Changes in Number and Characteristics of Institutions that Minority Students Sent Their Scores

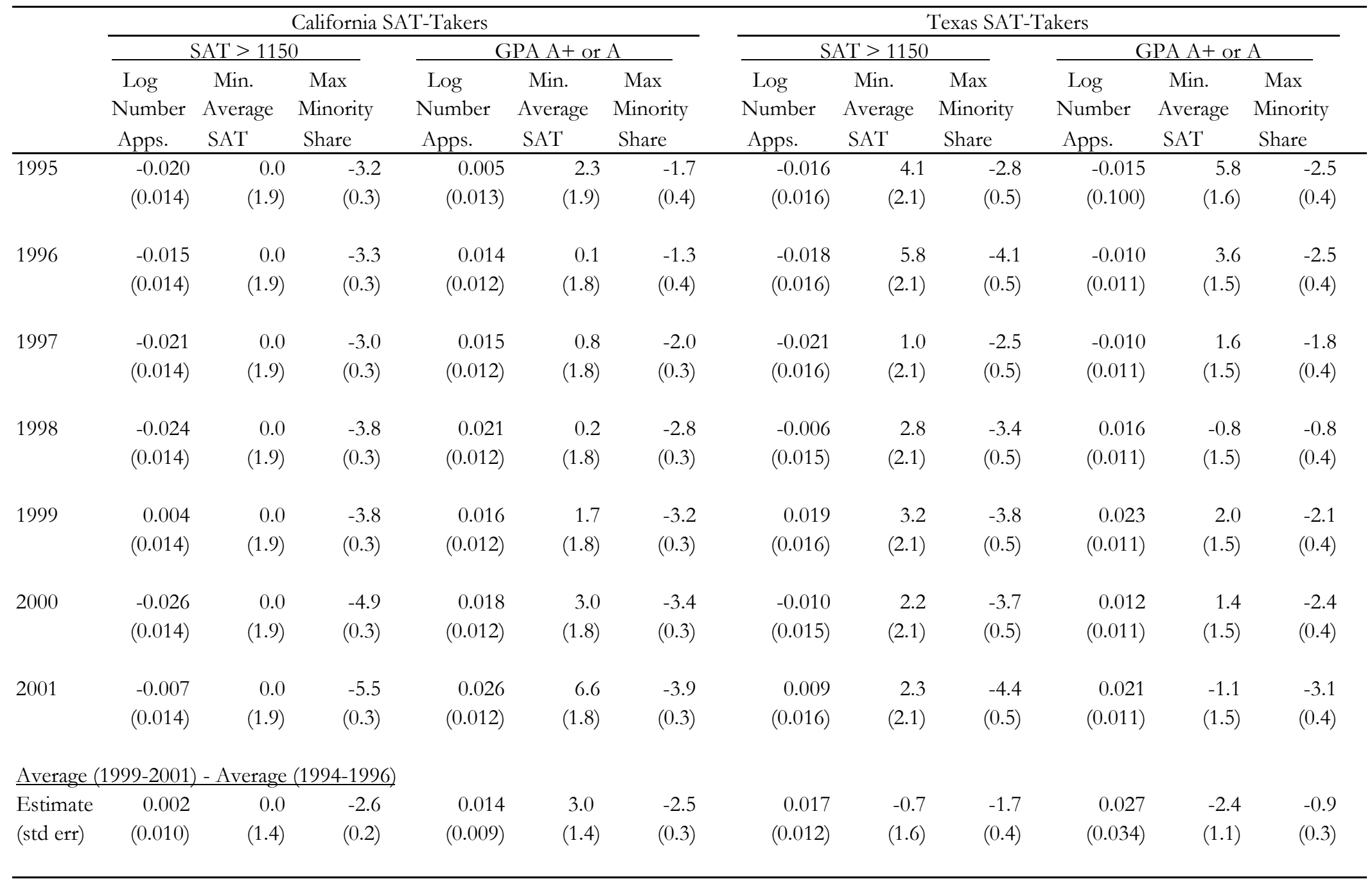

Note: Table shows estimates (and standard errors) of interaction of year dummies and minority ethnicity in models for the log of the number of schools to which SAR scores were sent, the minimum average SAT for the set of schools sent scores, and the maximum percent minority for the the set of schools set scores. All model include the same controls as in Table 4. 
Figure 1a: Admission Rates of Black Freshman Applicants

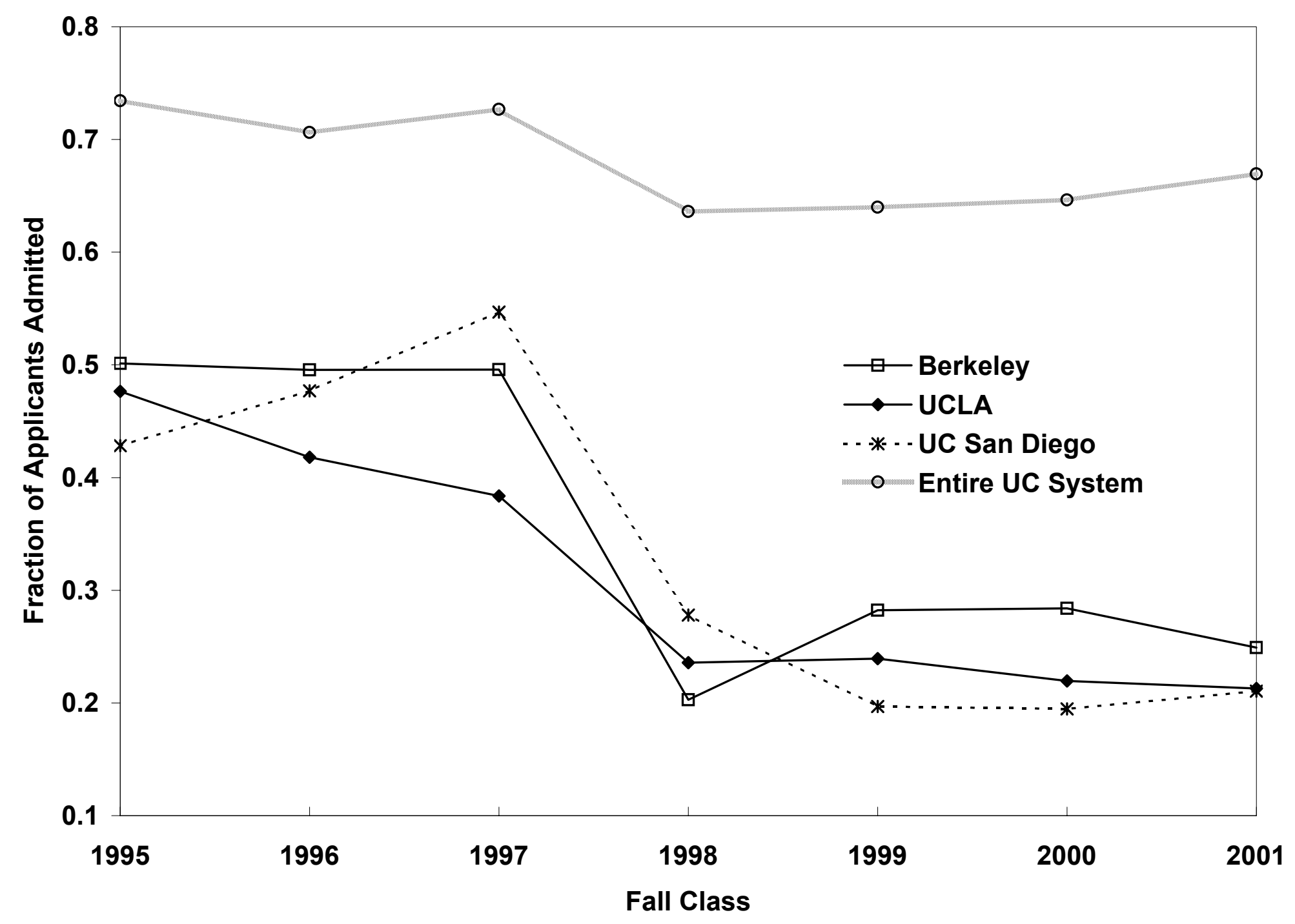


Figure 1b: Admission Rates of Hispanic Freshman Applicants

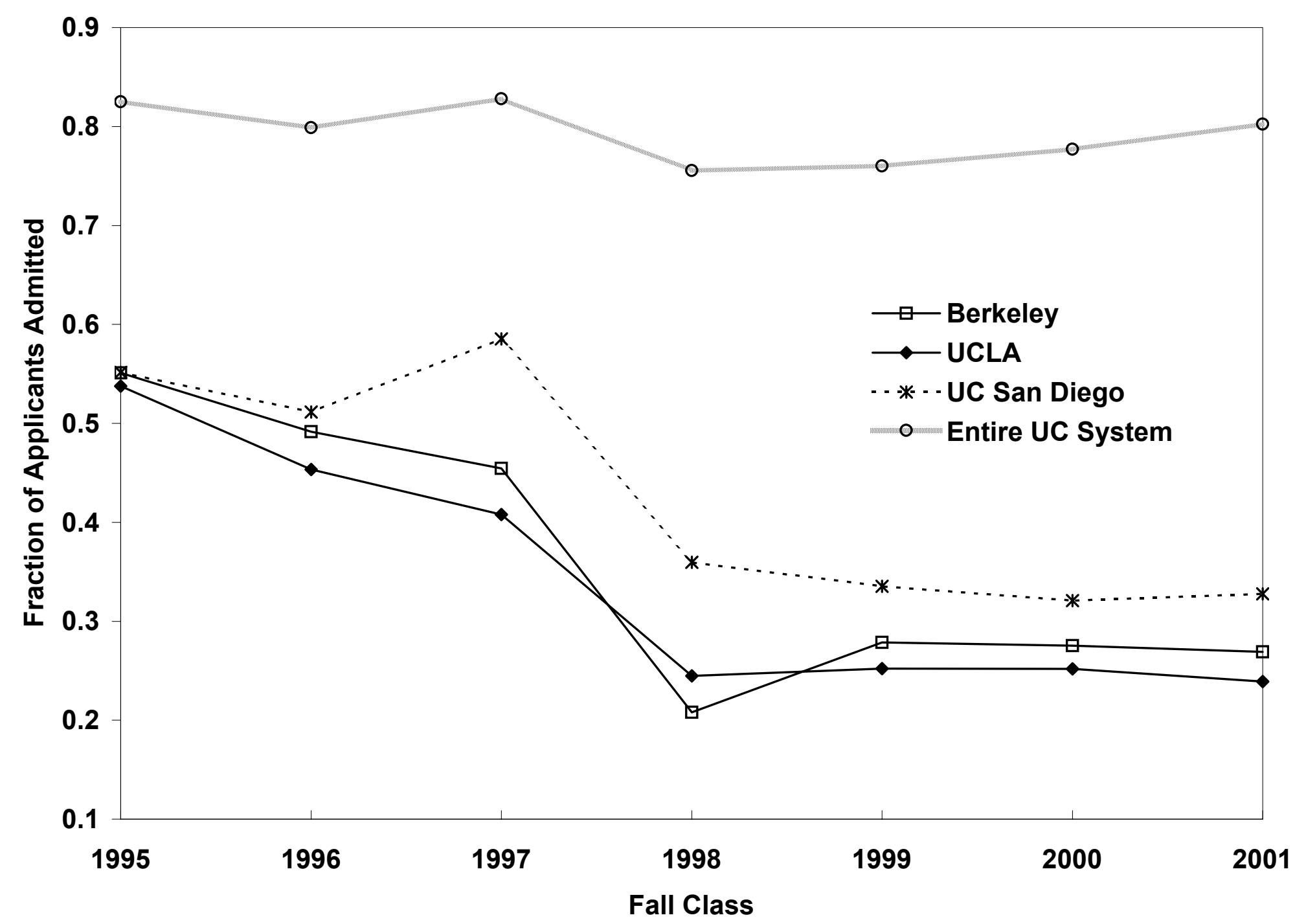


Figure 2a: Admission Rates of Freshman Applicants, Texas A\&M University

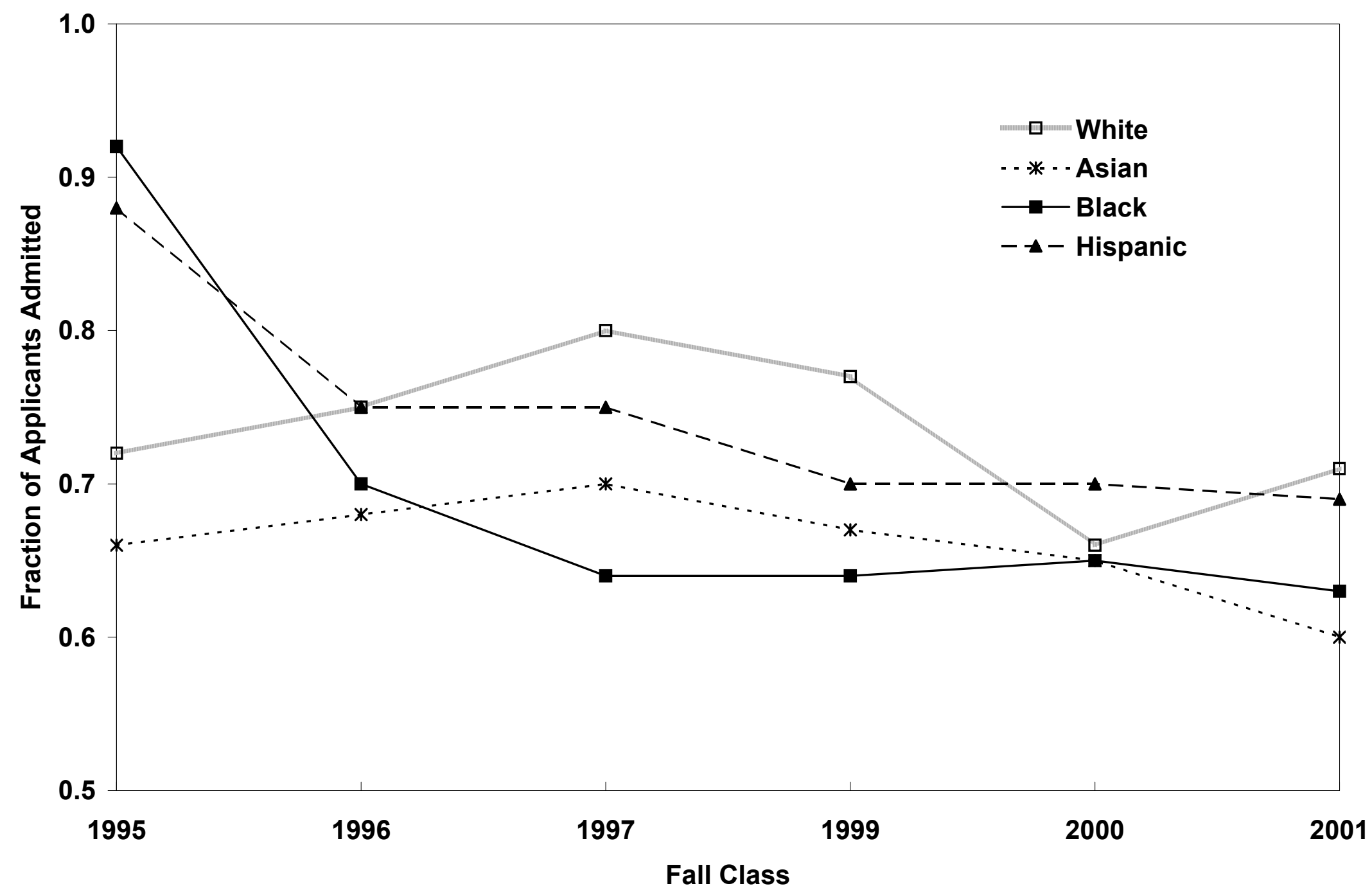


Figure 2b: Admission Rates of Freshman Applicants, University of Texas Austin

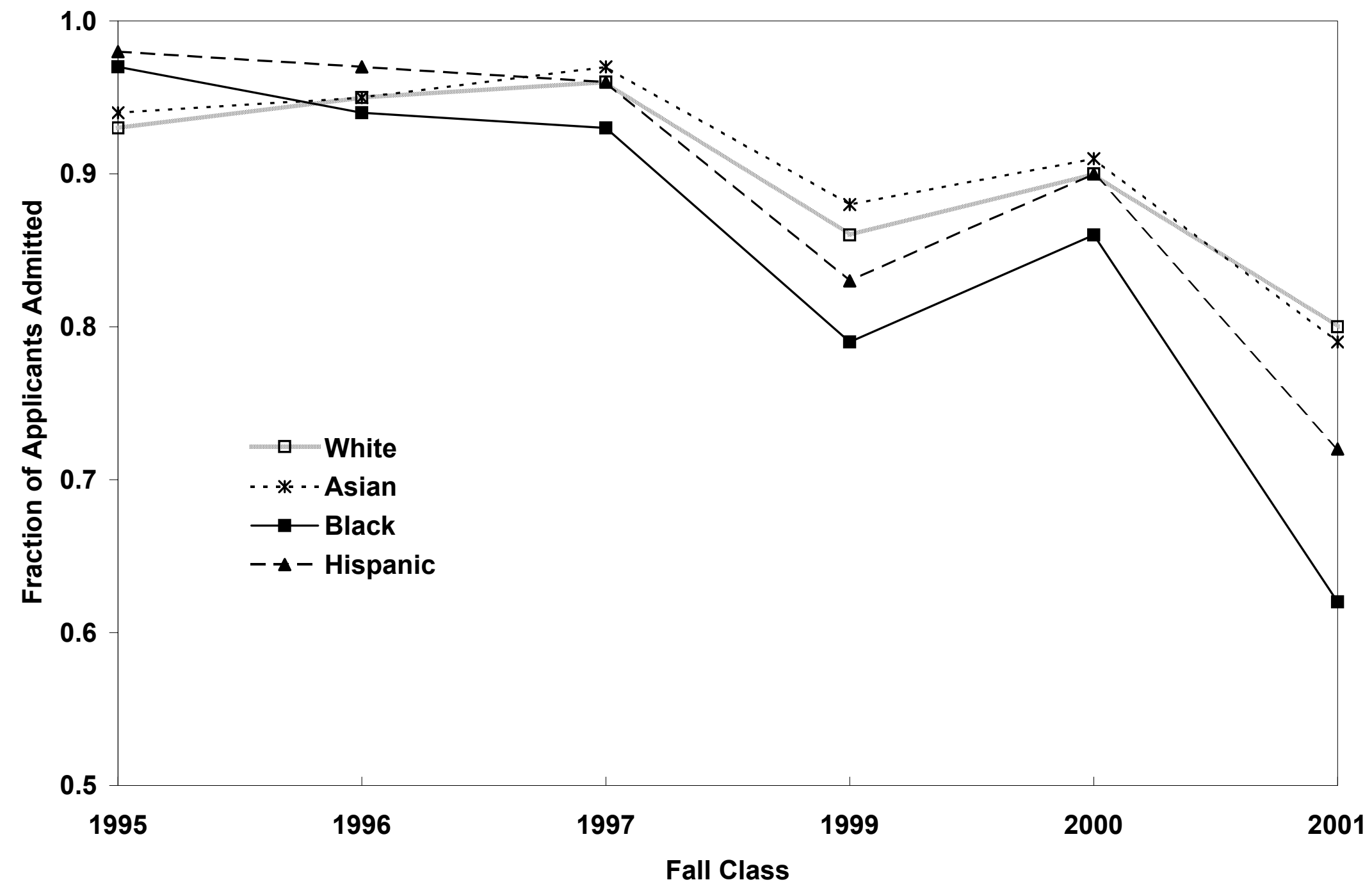


Figure 3a: Black-White Relative Application Rates to Most Selective UC Campuses

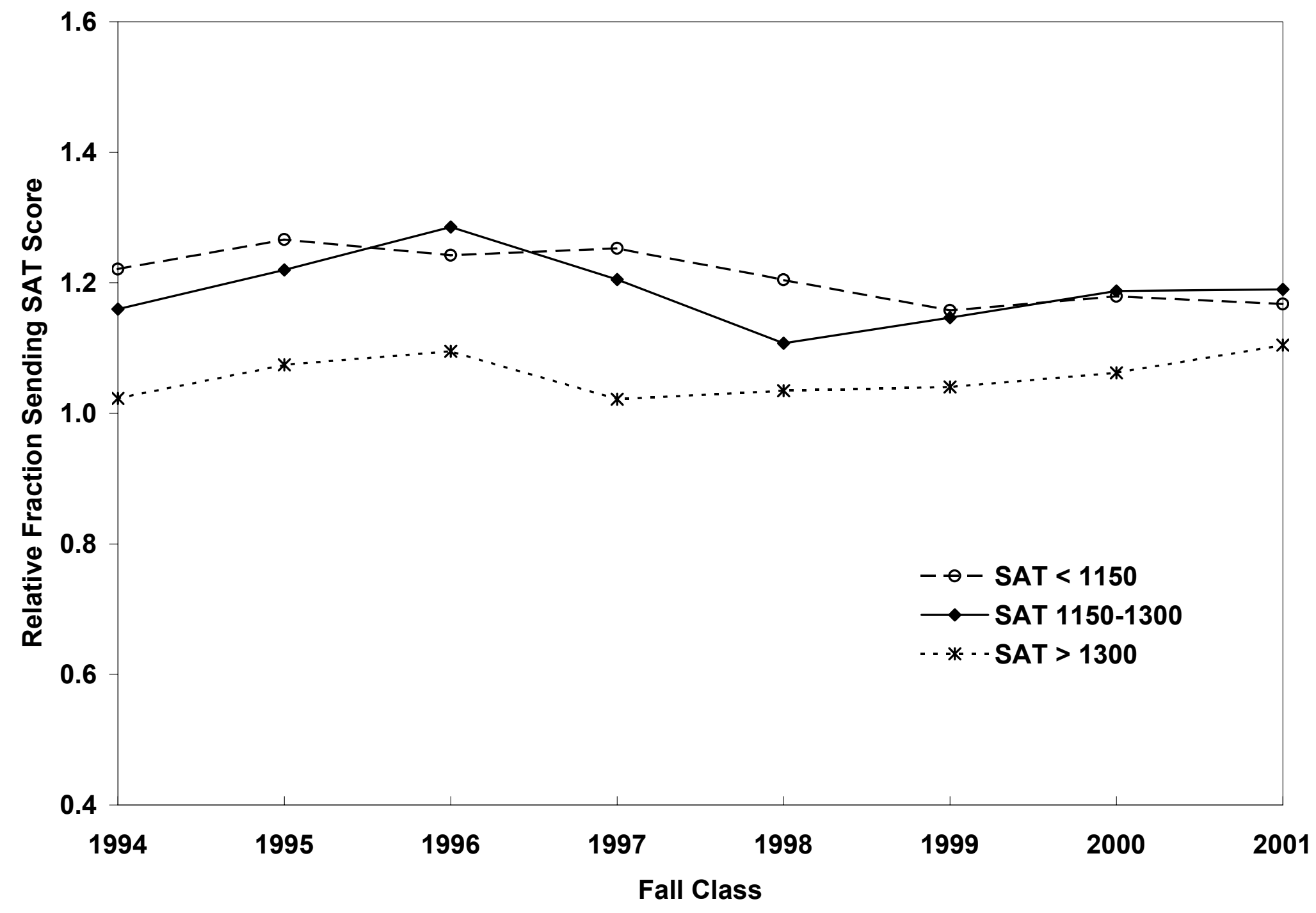


Figure 3b: Hispanic-White Relative Application Rates to Most Selective UC Campuses

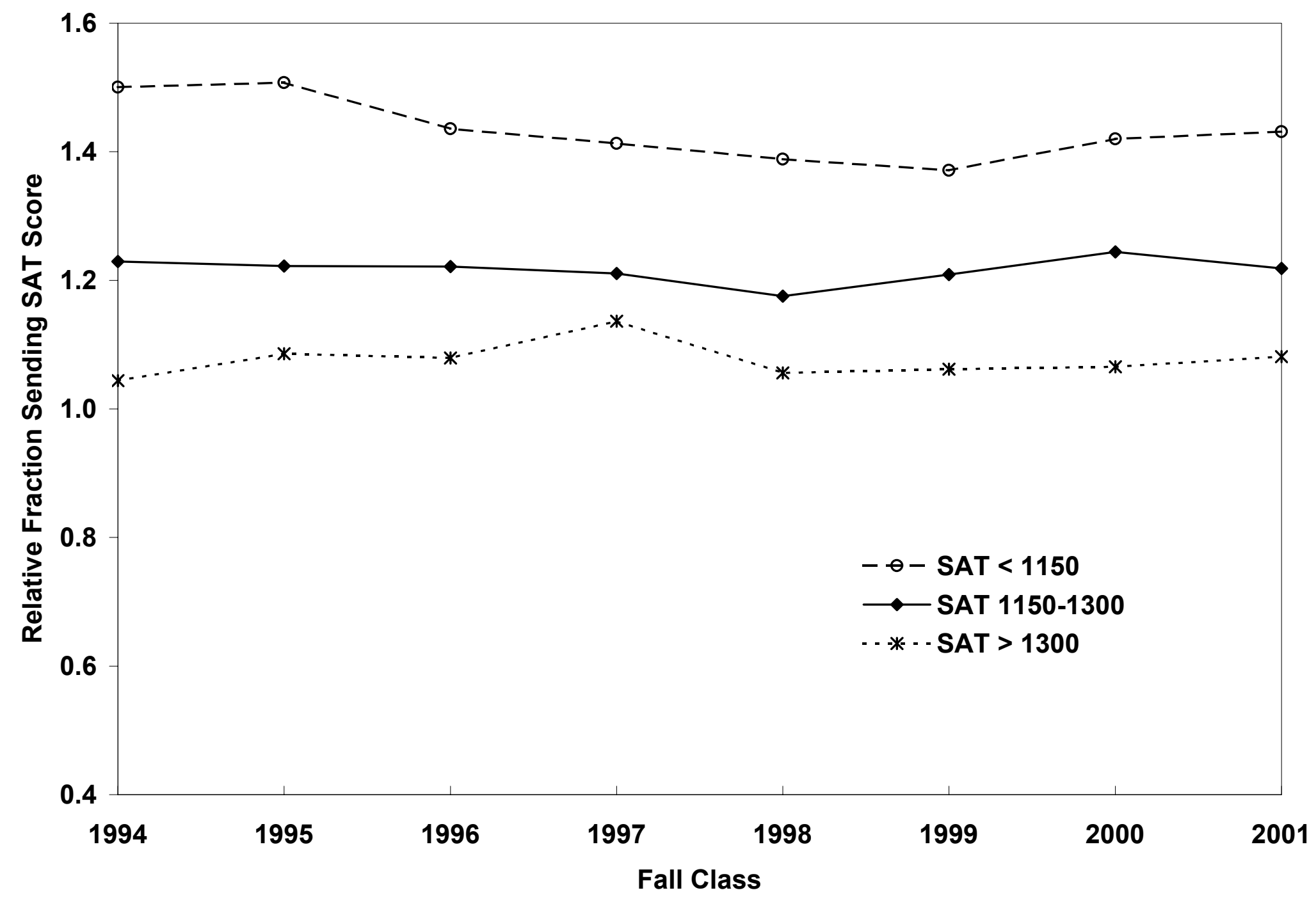


Figure 4a: Black-White Relative Application Rates to Most Selective Texas State Universities

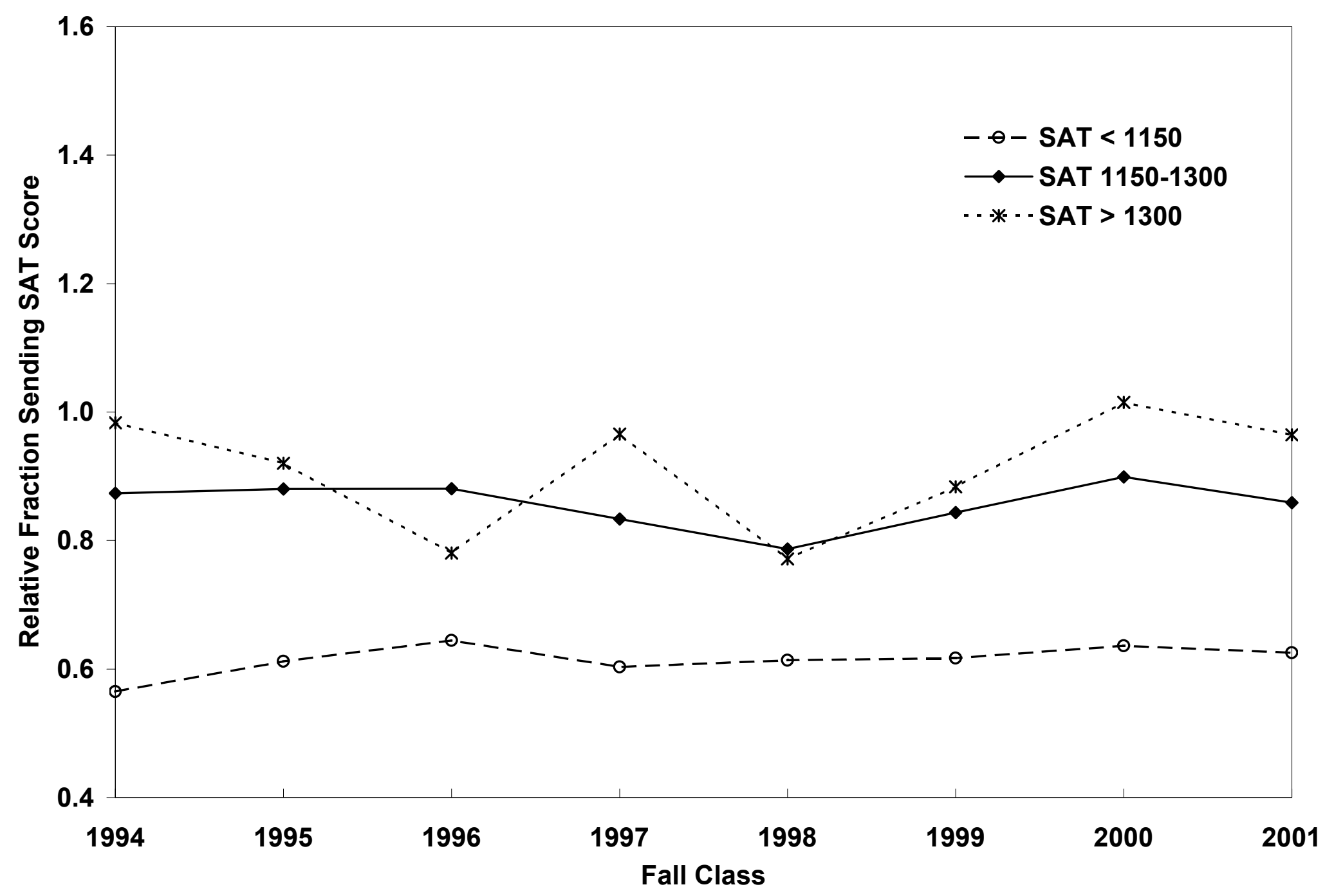


Figure 4b: Hispanic-White Relative Application Rates to Most Selective Texas State Universities

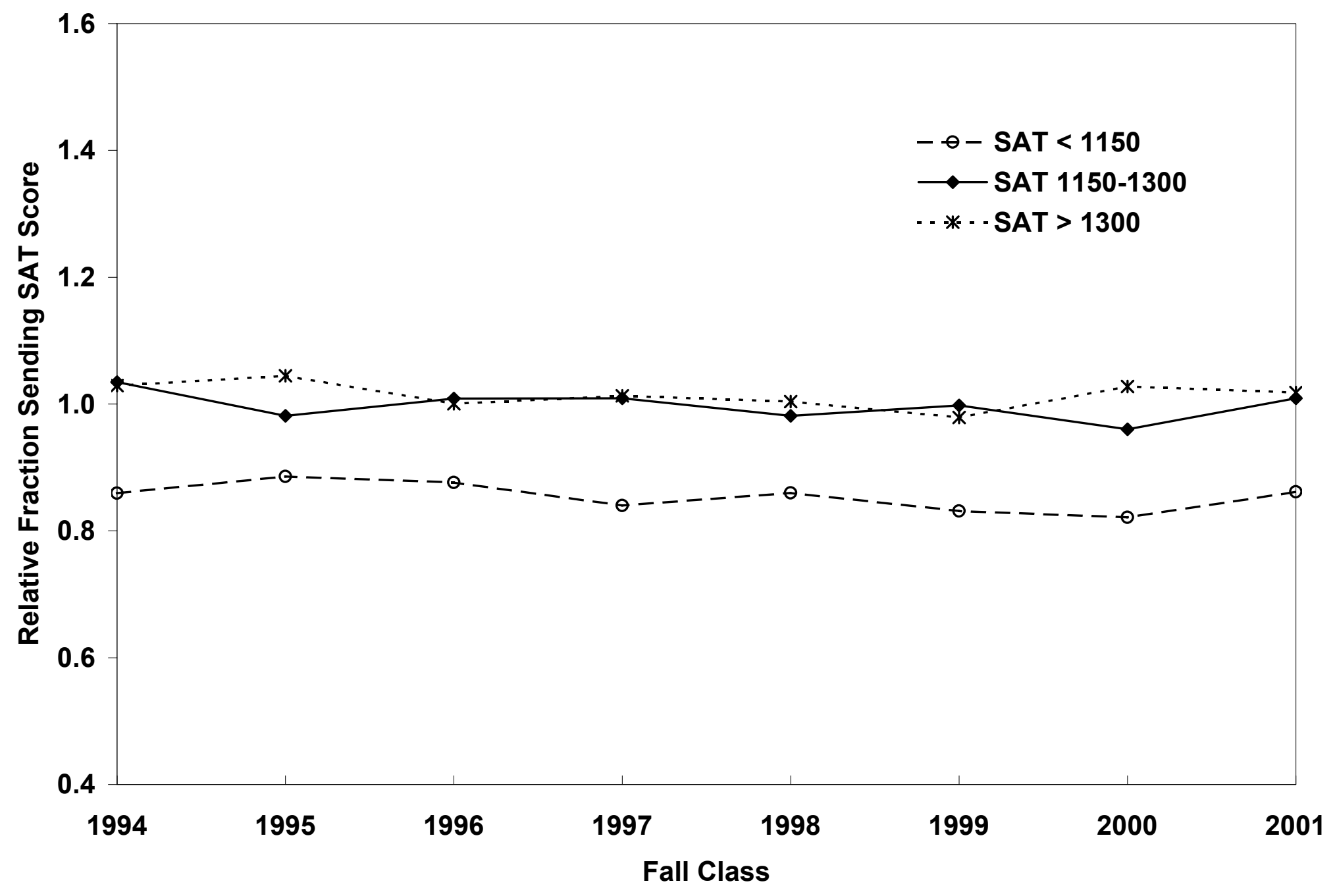

